Article

\title{
The Paths of Internationalization of Chinese Innovative Firms
}

\author{
Hongping Du ${ }^{1,2}, * \mathbb{D}$, Liliana Mitkova ${ }^{2}$ and Na Wang ${ }^{1}$ \\ 1 Business School, Sichuan University, No. 29 Jiuyanqiao Wangjiang Road, Chengdu 610064, China; \\ wangna.research@gmail.com \\ 2 LITEM Univ Evry, University of Paris Saclay, 2 Facteur Cheval, 91000 Evry, France; \\ liliana.mitkovadutel@univ-evry.fr \\ * Correspondence: hongpingduresearch@gmail.com; Tel.: +86-1872-8428-978
}

Received: 4 February 2020; Accepted: 22 March 2020; Published: 24 March 2020

check for updates

\begin{abstract}
Innovative enterprises from emerging markets, such as China, are a group of understudied enterprises, which could generate new and important views on internationalization. Some unique characteristics of Chinese innovative enterprises are creating new ideas that help to a better understanding of entry mode choice, market location choice, and entry speed in the paths of internationalization. Drawing on an unbalanced panel of Chinese innovative enterprises' outward foreign direct investment (OFDI) event data, we analyzed the tendency of the paths of internationalization of Chinese innovative enterprises and the determining factors that influence the Chinese innovative enterprises' choice in entry mode, market location, and entry speed. The results show that: (1) Chinese innovative enterprises are more likely to choose developing countries than developed countries. (2) When these firms conduct investment activities in developed countries, the probability rank (from high to low) of entry mode choice is acquisition, along with the wholly-owned subsidiary, exporting and joint venture. When these firms expand the business in developing countries, the entry mode of export is most likely to be chosen and the acquisition is least likely to be chosen. (3) This tendency and paths choice of internationalization in entry mode, market location and entry speed are influenced by the international experience, the multidimensional proximity, psychic distance, internationalization motivation, ownership structure, and innovation ability. Finally, we discuss these contributions and make some suggestions for future research.
\end{abstract}

Keywords: paths of internationalization; the entry mode; the market location; the entry speed; innovative firms

\section{Introduction}

In the past three decades, outward foreign direct investment activities have gradually become a regular option for the development strategy of the Chinese multinational enterprises (MNEs) under the new state of economic globalization. Internationalization of production and operation across national boundaries is the inevitable choice of enterprises' development, and internationalization will provide sustainable growth for the firm in the global market [1]. The outward FDI by the Chinese MNEs has been playing an increasingly important role all over the world since the implementation of "go out" policy in 2001 [2]. Furthermore, with the comprehensive promotion of "One Belt One Road" initiative policy, the Chinese MNEs accelerated the layout of international strategy in the world map [3]. Between 2001 and 2016, China witnessed a 68.5\% annual growth in outward foreign direct investment (OFDI) flow and has been the second-largest capital export country, surpassed only by the United States, since 2015 [4]. Hence, the rapid growth and the large scale of China's overseas investment have aroused the interest of researchers, business managers, and policy decision-makers, 
and have brought about more research on this subject. However, the paths of internationalization of Chinese MNEs seem to defy the fundamental theories of mainstream internationalization [5].

Even though the internationalization of Chinese MNEs has attracted researchers from the field of international business, organization and strategic management, the hypothesis and discovery of the theory are mainly based on the study of the entry mode choice, market location choice or the influence of internationalization on the firms' performance. Some findings regarding the paths of internationalization of Chinese MNEs from [2,6-8] are based on a case study, other research focused on only one dimension within the choice of entry mode [9-11] or the choice of foreign market $[8,12,13]$. On the one hand, previous studies lack a longitudinal research design addressing the internationalization of Chinese MNEs. They have especially ignored three dimensions of firms' internationalization (market location, entry mode and entry speed). On the other hand, it's difficult to avoid the problem of bias that arises in the case studies and questionnaire methods. Findings from such studies do not always represent the universal features of the paths of Chinese MNEs' internationalization. Therefore, despite the growing literature in the field of international business, our understanding of the paths of internationalization of Chinese innovative firms is limited.

According to recent studies [14-17], the Chinese MNEs have different paths of internationalization as with the traditional multinational enterprises from developing countries (DMNEs) and the multinational enterprises from other emerging economies (EMNEs), it appears that they internationalize in "wrong" ways. Firstly, it has been argued that some Chinese MNEs enter a new foreign market beginning with high-risk and high-commitment entry mode, such as establishing a wholly-owned subsidiary or implementing an acquisition, rather than beginning with low-risk and low-commitment options (such as export mode or joint venture) [5,18]. Secondly, Chinese MNEs appear to have a "wrong" sequence in targeted countries. Sometimes, the Chinese MNEs expand the boundary of internationalization activities to the countries with farther psychological distance before entering to the countries with closer psychological distance [2,13]. Thirdly, it has been argued that the Chinese MNEs have a much faster pace of internationalization than the traditional stage model $[15,19]$. The scope and boundary of the traditional internationalization process theory have some limitations, which is difficult to provide effective guidance for successors' paths of internationalization. Previous research sheds light on the differences among the Chinese MNEs' internationalization processes without suggesting the mechanism and the influencing factors of path selection.

Existing research on the path of internationalization of Chinese MNEs mostly focus on a single dimension such as the time of overseas entry, or the market location [9-11], or the entry mode [12,13], and analyze the path selection in the process of internationalization of enterprises statically. In order to explore the dynamic evolution of the path selection of MNEs in the process of internationalization systematically, our study uses the unique foreign investment data of Chinese innovative companies to analyze the historical behavior of path selection in the process of internationalization sequentially and to study the influence mechanism of different choices. Using original data from the Chinese innovative firms' OFDI events, this study simultaneously considers three key aspects concerning the paths of internationalization of innovative firms. We focus on a deeper understanding of three main components in the process of internationalization in particular: the entry mode, the market location and the entry speed. To reveal the factors that influence the paths of internationalization, we use the existing research dedicated to the process of internationalization $[2,6,17,20]$ and factors impacting different firms' internationalization strategies [15,21,22].

To achieve our research purposes above, we conducted an empirical study based on 981 OFDI event observations conducted by 156 Chinese innovative firms over a period of 27 years (from1991 to 2017). The results offer two main contributions to existing research. Our research contributes to improving the understanding of the paths of internationalization of EMNEs, in so far as it: (1) analyzes the way in which three key decisions in the paths of internationalization-entry mode choice, market location choice, and entry speed-are simultaneously made, and (2) reveals the factors affecting the paths of international of innovative firms, especially the effect of innovation ability 
on the internationalization. In summary, our contributions are the extension of existing theories (path-dependent and learning perspectives) to the internationalization of emerging contexts [23] and the unique functional relationships in the international context.

This study is organized as follows. In Section 2, the literature review concerning the internationalization processes with emphasis on the historical background of Chinese strategies is presented. Section 3 introduces empirical evidence about the data sources, research samples and analytical methods. Section 4 analyzes the features and the trends on the paths of internationalization by using Kaplan-Meier survival function and examines the determining factors affecting the MNEs' choice in the paths of internationalization. Finally, Section 5 concludes with a summary of the article, draws some managerial and policy implications, and outlines some ideas for future research.

\section{Innovative Firms and Internationalization}

\subsection{The Chinese Innovative Firms and Internationalization Policies}

The concept of an "innovative firm" stems from "innovation". The definition of what constitutes an innovative firm has varied over the past three decades [24-28]. Due to the differences in research perspectives and research backgrounds, there is not a unified definition of the concept of "innovative firm", but all are defined by the core of innovation. Therefore, in this study, we reference the definition of an innovative firm from the World Bank for the publication "Promoting Enterprise-Led Innovation in China". It states that the innovative firm should have core technology with independent intellectual property rights, continuous innovation ability, driven power in industry and independent brands, strong profitability and higher management level, innovative development strategy and innovative culture [29]. Internationalization of enterprises is one of the most important subjects in the field of strategic management. Previous studies defined the internationalization of enterprise from different theoretical perspectives [2,30-33]. This article considered the internationalization of enterprises as an investment in foreign markets. Luo and Tung [2] defined internationalization of enterprises from emerging markets, as engaging in OFDI implementing effective control and conducting value-added activities abroad. The relationship between internationalization of enterprise and innovation is influenced by many factors [34-38], the strategy of internationalization reduces the volatility of corporate income and corporate risk, which is beneficial to firms' continuous $R \& D$ investment and innovation [39].

China's strategy of building an innovative country has continuously cultivated a group of innovative enterprises. Since 2006, The Chinese government has launched the pilot work of innovative enterprises, which should be outstanding in five aspects. Moreover, the three departments set an evaluation index system to assess innovative enterprises from these pilot innovative enterprises. More specifically, the evaluation index system includes the ratio of R\&D expenditures to total revenue, the number of patents per thousand researchers, the ratio of new products' sales revenue to main business revenue, the labour productivity of the whole company, and the innovation of organization and management. Accordingly, three departments evaluated 356 innovation firms from 550 pilot innovative firms between 2008 and 2011, and the remaining 194 pilot innovative firms did not meet the indicators of innovative firms. The government of China clearly emphasized the goal to cultivate a scale of world-class innovative enterprises and the important significance of innovation firm influence on economic development in the "Outline of Innovation-Driven Development Strategy" in 2016 [40].

The Chinese government has developed a series of preferential policies to provide a beneficial international environment for Chinese enterprises to go out. Firstly, the Chinese government has launched the strategies of "go out" and "One Belt One Road" to promote international activities. The government proposed that Chinese multinational firms "go out" as one of the four new national strategies since 2000, and the Chinese government decided to support enterprises that "go out" and carry out international business activities during the National Business Work Conference in 2006 [2]. In 2012, China not only required enterprises to accelerate the pace of internationalization but also proposed 
a goal to nurture a group of world-class multinational enterprises [41]. In 2013, The government proposed a new strategic cooperation framework "One Belt One Road" to promote cooperation between MNEs and other major regions and countries [42,43]. Secondly, China's relevant ministries and agencies have jointly proposed various measures [11,41,44]. As mentioned by Luo, et al. [45], the outward FDI promotion policies made by the Chinese government are economically necessary and complementary to the system to offset the discounts the disadvantages of MNCs in global competition. Therefore, such profitable macro policies and institutional incentives significantly promote the internationalization process of Chinese companies.

There is a gap in the literature on the internationalization of Chinese companies: what are the innovative enterprises' internationalization process, especially for Chinese firms that need internationalization. Therefore, it is necessary to conduct in-depth studies about the paths of Chinese innovative enterprises, include the entry mode of international expansion, the market location, and entry speed.

\subsection{The Paths of Internationalization}

Concerning previous studies $[2,9,15,46,47]$, this article focuses on the entry mode, market location, and entry speed, because these factors are the three most critical dimensions in the path of internationalization of multinational corporations, and they are of strategic importance to the enterprises' business [48]. Therefore, the following three sections will introduce and review related research.

\subsubsection{The Entry Mode of the International Expansion}

Research on the choice of entry mode of the multinational corporation has always been a key area in the paths of internationalization. Entry mode can be defined as an institutional arrangement that would have a significant influence on firms' decision-making in the future [49]. Each enterprise could choose the entry mode such as export, joint venture, strategic alliance, WOS (wholly-owned subsidiary), M\&A (merger \& acquisition), and other access options to conduct international activities [46,50]. Firstly, Export is one of the most important entry modes for companies to expand their business and market bases to another country in order to gain more opportunities and achieve better performance [51-55]. In this study, we measure the export channel as a company's office or agents branch channel located overseas using self-managed operations in export (hierarchical modes) [56]. Secondly, an equity joint venture is an economically and legally independent organizational entity in which over and above two parent organizations jointly invest in resources for the pursuit of certain objectives $[57,58]$. The joint venture represents a longer-term cooperation strategy which compares to the contractual forms of interfirm cooperation [59]. Thirdly, the WOS entity has become and continue to be an important tool for companies seeking opportunities in foreign markets, especially to remove intellectual property barriers around the world [60]. However, there is a distinction between this entry mode and a joint venture, for example, this entry mode doesn't involve minority shareholder, and the parent company owns all the shares of the wholly-owned subsidiary. Furthermore, another important foreign entry mode is acquisition, which is a high-control commitment [61]. The reason behind the acquisition is generally that the consolidation of two independent companies could create higher value than one company.

Based on existing studies, the international entry mode choice in the Chinese context mainly included: (1) entry through joint ventures or through wholly-owned subsidiaries [10,62,63], and (2) entry through greenfield investment or international acquisition [13,64-66]. Cui and Jiang [10] found that when seeking assets to be the main purpose in OFDI, Chinese companies are more inclined to establish the wholly-owned subsidiary instead of the joint venture, but a joint venture is preferred when the firm is investing in a high growth host market. Furthermore, some Chinese companies are trying to fill a huge knowledge gap through acquisitions, which inhibit them from competing on the global stage $[2,7,13]$. Anderson, et al. [67] found that "compared with the entry mode of greenfield investment, Chinese enterprises seek strategic assets in developed countries to carry out internationalization mainly through $M \& A^{\prime \prime}$. Liou [68] held the opinion that the industrial sector will 
affect the Chinese firms' overseas transactions. For example, China's large oil and gas companies tend to choose M\&A due to lack of resources and similar M\&A transactions in the history of the industry.

\subsubsection{The Market Location}

Overseas location choice of MNCs is another important dimension of the path of internationalization. These MNCs have important advantages when the overseas branches of enterprises are in suitable countries or regions. The existing research on the location selection of EMNEs' internationalization mainly focuses on the host country's choice between emerging economies and developed economies. The main influencing factors include the host country system [11], the internationalization motivation [10,69], host country resource endowment [70] and strategic assets [71].

Specifically, research on Chinese firms' location choice was mainly focused on the choice between emerging economies and developed economies. Because China is a middle-income country, Chinese multinational corporations not only could participate in some outward FDI activities in developed countries that are richer than China but also could choose to go to other developing countries with lower income levels [72,73]. Cuervo-Cazurra and Genc [74] found that most EMNEs choose to expand overseas in emerging economies because they have less regulation and less control of corruption, and they have more operating room in overseas expansion through the system. For example, some Chinese multinational corporations tend to invest abroad in certain tax-avoidance countries and Southeast Asia countries [75]. However, Ramamurti found that the choice of location for Chinese multinationals may depend on the ownership structure, and state-owned enterprises tend to choose these regions with abundant natural resources and less political risk, while private firms pay more attention to the host countries' market size and production efficiency [5]. In general, the choice of EMNEs for internationalized locations is still dominated by developing countries, and a few companies will enter developed countries through mergers and acquisitions [76].

\subsubsection{The Entry Speeds}

As the dimension of time and change in the international "process", the importance of the concept of internationalization speed is increasingly valued. At present, compared with the research about how to carry out an international strategy quickly after this enterprises' establishment, there are relatively few studies on the "initial speed" and "post-entry speed" of companies (e.g., Casillas and Acedo [77]; Hilmersson and Johanson [78]). In recent years, some scholars have begun to deeply analyze the conceptual connotation of the speed of internationalization and began to construct relevant theoretical models $[79,80]$. However, some related studies have either described changes in specific internationalization states or failed to explicitly state the division between internationalization and time, so they fail to accurately define the speed of internationalization. In line with past research $[23,47,81]$, we measured the entry speed as "the average number of foreign outlets divided by the number of years since the company's initial international expansion. This measure is particularly suited when studying the internationalization of large MNEs [82].

At the same time, the factors affecting the speed of internationalization of enterprises have attracted the attention of researchers. At the organizational level, knowledge and capacity are the main drivers of internationalization speed. Existing research not only examines the direct impact of the type and characteristics of organizational knowledge on the speed of internationalization $[23,83]$ but also analyzes the moderator effect of empirical knowledge on the relationship between strategic factors and internationalization speeds [23]. In the inter-organizational level, the network is a decisive factor for the speed of internationalization. Although the academic community recognizes the value of relational networks in the study of internationalization speeds, the impact of different dimensions of the relationship network on the speed of internationalization is vastly different [84]. At the institutional level, the host country system, home country system and infrastructure are the main influencing factors in the speed of internationalization $[85,86]$. 


\subsection{The Determining Factors and the Internationalization Path}

The internationalization process of multinational enterprises is affected by many genes, including internal and outside constituents. Internal factors include the firm age, ownership structure, innovation ability, international experience, international motivation. The external elements include the host nation, such as the economic level, the political risk level, geographical localization and ethnic elements.

In fact, internal factors have the most significant and direct impact on the enterprises' international expansion. Based on the perspective of resource-based theory, previous research shows that the size of the enterprise [21], the age of the enterprise [87], and the accumulation of international experience [88] have positive relationships with enterprises' overseas expansion. Other studies found that host country experience is related to acquisitions [89,90]. Based on the knowledge-based theory, Dow and Larimo [91] discovered that both the cluster-specific experiential knowledge and general international knowledge are significantly related to the entry mode choice, but in the opposite direction [92,93]. In addition, based on the institutional foundation, Ramasamy, Yeung, and Laforet found that ownership structure is an important factor affecting the location of overseas investment. State-owned enterprises tend to choose countries or regions with abundant natural resources and fewer political risks, while private enterprises are more concerned with the market potential of host countries [9].

However, the impact of the external environments, especially the relationship of factors with the host countries on the international path is becoming increasingly prominent. These factors include the characteristics of the host country and the distance (and proximity) between the host country and home country [94]. On the one hand, the host country's macro-economic and financial market environment has attracted the attention of multinational enterprises [94,95]. Meanwhile, these multidimensional proximity factors such as institutional, language, nature, geographic, and economic proximity influence international decision-making are more complex than other factors [96-98]. On the other hand, the academic community has also developed some standards to measure the differences between the host country and the home country. The most frequently used is the distance between certain characteristics of the host country and the home country, such as cultural distance [99], institutional distance, geographical distance [95], and psychological distance [100]. Based on the multi-dimensional psychological distance measurement tools developed by Blomkvist and Drogendijk [101] and Dow and Karunaratna [102], the results confirm that psychological distance has a large influence on the entry mode selection, trade and market selection of the internationalization process of enterprises in emerging countries.

To summarize, the issue here is like what we discussed earlier: previous studies have not considered the influencing factors of innovative enterprises in the path of internationalization, especially these multinational corporations from emerging countries. This opening creates an estimated problem by the comparison of effects. Moreover, it only exists in a market and couldn't meaningfully explain the specific situation that may lead to a preference for a greenfield or an acquisition, developed countries or developing countries, slow or fast entry speed.

\section{Methods}

\subsection{Data Sources and Research Sample}

We constructed an unbalanced panel data set for the period of 1991-2017 to explore the paths of internationalization of Chinese innovative firms. We employ two novel firm-level data set.

The first dataset consists of information with 356 innovative firms. The list of innovative firms was obtained from the Ministry of Science and Technology of the People's Republic of China (MOST) [101]. Enterprises bear the main responsibility of national innovation development in China. Therefore, three Chinese central organizations (that consisted of MOST, the State Asset Supervision and Administration Commission and the All China Federation of Trade Unions) have evaluated 356 innovative firms (the first batch of 91 national innovative enterprises was assessed and determined in 2008, the second batch of 111 innovative enterprises was released in 2009, and the third batch of 154 innovative enterprises 
was evaluated and announced in 2011) based on five evaluation indicators. These evaluation indicators include the ratio of $R \& D$ expenditures to total revenue, the number of patents per thousand researchers, the ratio of new products' sales revenue to main business revenue, the labour productivity of the whole company, the innovation of organization and management. Then we obtained the firm-level information from the official website of innovative firms, such as the date of establishment, the registered address, business nature, and industry.

The second dataset consists of information with firms' OFDI event. It was obtained from the Ministry of Commerce of the People's Republic of China (MOFCOM), which announced systematic OFDI information of Chinese enterprises from 1991 to 2017, including the name of foreign investment firms, the name of overseas subsidiaries/branches, the business scope of foreign subsidiaries /branches, investment location and the date of approval. As the public official statistical data, it has been widely applied to IB research $[103,104]$. To reflect the real state of Chinese firms' Outward FDI, it is worth noting that this study excludes the bias of research possibly resulted from the "reverse/round-tripping" investments (i.e., Returning to the country with its own funds under the name of "foreign" subsidiary company to obtain preferential treatment from the home government) [2]. The enterprises didn't engage in value-adding activities, and the "round-tripping investment" was not truly "go out" but "bring in", which belongs to policy rent-seeking [105]. Therefore, this study excluded these OFDI event observations which the investment locations are Hong Kong, Macao, Taiwan and BVI (Bermuda, British Virgin and Cayman Islands) [106-108]. Finally, the sample included about 38847 firms who invested in 55398 overseas projects.

After merging these two databases and filtering out innovative firms' OFDI observations, the final obtainable dataset includes 156 innovative firms with complete information. We further check each investment event and identify the overseas entry mode (exporting, joint venture, a wholly-owned subsidiary, and acquisition) from the official website or annual report of innovative firms. Finally, we have left 981 observations with 156 innovative firms between the period between 1991 and 2017.

Table 1 reports descriptive statistics. Section A displays that the location of OFDI of the sample of Chinese innovative enterprises OFDI location was concentrated in developed countries, not in developing countries. Section B shows that the foreign entry mode of exporting and the wholly-owned subsidiary was more than the foreign entry mode of acquisition and joint venture.

Of 156 innovative firms conducted the outward FDI in the data: 89 firms choose the exporting (455 observations), 51 firms choose the joint venture ( 87 observations), 101 firms choose the entry mode of WOS (329 observations), and 56 firms choose the entry mode of acquisition (110 observations). Section C shows that the sample of Chinese innovative firms is clustered in the manufacturing industry, scientific research and technology services, and mining. These industries could provide more strategic assets, such as technology opportunities, learning through observing, and sharing other foreign enterprises' experience [74].

Table 1. Location of outward foreign direct investment (OFDI), entry mode of OFDI, and industry distribution of sample firms.

\begin{tabular}{|c|c|c|}
\hline Section A: Locations of OFDI & No. of innovative firms & $\begin{array}{l}\text { No. of subsidiary/branch-year } \\
\text { observations }\end{array}$ \\
\hline Developed countries & $126(80.77 \%)$ & $431(43.93 \%)$ \\
\hline Developing countries & $96(61.54 \%)$ & $550(56.06 \%)$ \\
\hline Total & 156 & 981 \\
\hline Section B: Entry mode of OFDI & No. of innovative firms & $\begin{array}{l}\text { No. of subsidiary/branch-year } \\
\text { observations }\end{array}$ \\
\hline Exporting & $86(55.12 \%)$ & $455(46.38 \%)$ \\
\hline Joint venture & $49(31.41 \%)$ & $87(8.87 \%)$ \\
\hline Wholly-owned subsidiary & $100(64.10 \%)$ & $329(33.54 \%)$ \\
\hline Acquisition & $54(34.61 \%)$ & $110(11.21 \%)$ \\
\hline Total & 156 & 981 \\
\hline
\end{tabular}


Table 1. Cont.

\begin{tabular}{lll}
\hline Section C: Industry distribution of sample firms & No. of innovative firms & $\begin{array}{l}\text { No. of subsidiary/branch-year } \\
\text { observations }\end{array}$ \\
\hline Mining & $12(7.69 \%)$ & $76(7.75 \%)$ \\
Electricity, heat, gas and water production and supply & $2(1.28 \%)$ & $22(2.243 \%)$ \\
Building construction & $4(2.56 \%)$ & $20(2.04 \%)$ \\
Transport, storage and post & $3(1.92 \%)$ & $12(1.22 \%)$ \\
Scientific research and technology services & $13(8.33 \%)$ & $18(1.83 \%)$ \\
Agriculture, forestry, animal husbandry and fishery & $1(0.64 \%)$ & $19(1.94 \%)$ \\
Wholesale and retail trade & $5(3.21 \%)$ & $14(1.43 \%)$ \\
Information transmission, software, and information & $6(3.85 \%)$ & $25(2.55 \%)$ \\
technology services & $109(69.87 \%)$ & $772(78.70 \%)$ \\
Manufacturing & $2(1.28 \%)$ & $3(0.31 \%)$ \\
Leasing and business services & 156 & 981 \\
Total & No. of innovative firms & $\begin{array}{l}\text { No. of subsidiary/branch-year } \\
\text { observations }\end{array}$ \\
\hline Section D: State ownership of sample firms & $32(20.51 \%)$ & $219(22.32 \%)$ \\
\hline SOEs affiliated to local governments (SOELGs) & $90(57.69 \%)$ & $470(47.91 \%)$ \\
Private investors (PI) & $34(21.79 \%)$ & $292(29.77 \%)$ \\
State-owned Asset Supervision and Administration & 156 & 981 \\
Commission (SASAC) & & \\
Total & & \\
\hline
\end{tabular}

\subsection{Variables}

Table 2 contains the measures of variables and data sources.

Table 2. Variables, measures and sources.

\begin{tabular}{|c|c|c|}
\hline Variables & Measures & Sources \\
\hline Location choice & $\begin{array}{l}\text { Equal to } 1 \text { for developed country (if DGPP }>\text { China); } 0 \text { for } \\
\text { developing country (if DGPP < China). }\end{array}$ & MOFCOM \\
\hline Entry mode choice & Equal to 1 for exporting; 2 for JV; 3 for WOS; 4 for Acquisition & MOFCOM \\
\hline Entry speed & $\begin{array}{l}\text { The number of days between the operation and the immediate prior } \\
\text { operation of the firm. }\end{array}$ & MOFCOM \\
\hline Host country experience & The number of years a firm has operated it OFDI in a host country. & MOFCOM \\
\hline Entry mode experience & $\begin{array}{l}\text { The number of overseas subsidiaries/branches a focal firm has } \\
\text { chosen with specific entry mode. }\end{array}$ & MOFCOM \\
\hline Motivations of OFDI & $\begin{array}{l}\text { (1) Equal to } 1 \text { for resource-seeking, } 0 \text { otherwise; } \\
\text { (2) Equal to } 1 \text { for market-seeking, } 0 \text { otherwise; } \\
\text { (3) Equal to } 1 \text { for technology-seeking, } 0 \text { otherwise; } \\
\text { (4) Equal to } 1 \text { for strategic asset-seeking, } 0 \text { otherwise; } \\
\text { (5) Equal to } 1 \text { for global strategy, } 0 \text { otherwise; }\end{array}$ & MOFCOM \\
\hline Psychic distance & $\begin{array}{l}\text { The distance between home and host country that factors preventing } \\
\text { or disturbing the flow of information between firms and markets. }\end{array}$ & Blomkvist, K et al. [101] \\
\hline Institutional proximity & $\begin{array}{l}\text { Equal to } 1 \text { if China and the host country own a similar system } \\
\text { characteristic; } 0 \text { otherwise. }\end{array}$ & CEPII's database \\
\hline Language proximity & $\begin{array}{l}\text { Equal to } 1 \text { if China and the host country use the same official } \\
\text { language; } 0 \text { otherwise. }\end{array}$ & CEPII's database \\
\hline Nature proximity & $\begin{array}{l}\text { Equal to } 1 \text { if China and the host country belong to the same cultural } \\
\text { circle, } 0 \text { otherwise. }\end{array}$ & Blomkvist, K et al. [101] \\
\hline Geographic proximity & The distance between Beijing and host country's capital, unit(KM). & CEPII's database \\
\hline Economic proximity & $\begin{array}{l}\text { Equal to } 1 \text { if China and the host country belong to the same income } \\
\text { group; } 0 \text { otherwise. }\end{array}$ & The World Bank \\
\hline Firm age & The number of years since a firm has operated & Annual report \\
\hline $\begin{array}{l}\text { International innovation } \\
\text { ability }\end{array}$ & The number of PCT patents granted by WIPO. & $\begin{array}{l}\text { https://patentscope.wipo. } \\
\text { int/search/en/search.jsf }\end{array}$ \\
\hline $\begin{array}{l}\text { Domestic innovation } \\
\text { ability }\end{array}$ & The number of Chinese patents granted by SIPO. & $\begin{array}{l}\text { http://www.pss-system. } \\
\text { gov.cn/ }\end{array}$ \\
\hline
\end{tabular}


Table 2. Cont.

\begin{tabular}{lll}
\hline \multicolumn{1}{c}{ Variables } & \multicolumn{1}{c}{ Measures } & Sources \\
\hline Stock listed & Equal to 1 for listed enterprises, 0 otherwise. & Annual report \\
\hline Ownership structure & Equal to 3 for SASAC, 2 for SOELGs, and 1for PI. & Annual report \\
\hline Industry policy & $\begin{array}{l}\text { Equal to 1 if the firm operates in the encouraged industry in the } \\
\text { specific country, 0 otherwise. }\end{array}$ & MOFCOM \\
\hline Marketization & The level of marketization in different provinces of China. & $\begin{array}{l}\text { The National Economic } \\
\text { Research Institute index }\end{array}$ \\
\hline Industry dummies & 1, if the MNE is in a given industry; 0, otherwise. & Annual report \\
\hline Year dummies & 1, if the foreign entry is in a given year; 0, otherwise. & MOFCOM \\
\hline
\end{tabular}

\subsubsection{Dependent Variables}

In order to study the paths of internationalization of Chinese innovative firms, we examined three significant dependent variables. These variables are used in Table 2.

Entry mode choice. It is a categorical variable indicating the entry mode that a specific firm has selected. We measure and recognize the foreign entry mode by checking each innovative firms' official website and annual report. According to the principle of data statistics of MOFCOM, these entry modes in our study include exporting, a wholly-owned subsidiary, joint venture and acquisition. In this inquiry, the exporting entry mode is evaluated as the institution of a new foreign branch or agency abroad, the wholly-owned subsidiary is measured as the establishment of a new foreign subsidiary operation, and the stock right should be owned by only one parent. The joint venture means a new subsidiary established by two or more parents together, and acquisition is measured as the purchase of an existing company in the host country by an MNE [109]. Therefore, we measure the variable of entry mode choice as 1 for the exporting, 2 for the joint venture, 3 for the wholly-owned subsidiary, and 4 for the acquisition.

Location choice. It is a dummy variable indicating the selection level of market location. This study uses the same definition of "foreign location choice" as the World Bank (2016), who constructed the foreign location choice as developed countries or developing countries. We measure the variable as 1 for developed countries and 0 for developing countries $[73,103]$.

Entry speed. We calculated the time between the focal OFDI event and the one immediately thereafter (number of days) as an indicator of the entry speed of the internationalization. Therefore, the entry speed of a focal OFDI activity has been measured as the number of days between the focal operation and the immediate prior operation of the same firm $[23,110,111]$.

\subsubsection{Independent Variables}

This research also includes several determining variables. Firstly, host country experience and entry mode experience are valuable and inimitable firm-specific resource accumulated over time. Host country experience is measured by the number of years a focal firm has operated in a specific host country since its first OFDI activity in that country [87,112-114]. Entry mode experience is measured by the number of overseas subsidiaries/branches a focal firm has built with specific entry mode [115-117]. Secondly, we measure and identify the motivation of internationalization as five dummy variables based on the business scope of each branch/subsidiary, the motivations contain resource-seeking $[118,119]$, technology-seeking [120], market-seeking, strategic [121,122], assets-seeking [10,20,67,123], and the global strategic-seeking $[2,9,10,124,125]$. We equal the motivations to 1 for the business of foreign subsidiary/branch containing the contents what we set, otherwise 0 .

Thirdly, we take into firm age, international innovation ability and domestic innovation ability account the possible explanation from the resource-based theory. We measured the firms' age as the number of years since incorporation $[87,126]$. We measured the firms' international innovation ability as the number of granted PCT patents from the World Intellectual Property Organization (WIPO) [127] and measured the domestic innovation ability as the number of granted Chinese patents from the 
State Intellectual Property office of the P.R.C (SIPO) $[6,66]$. Fourth, we consider the industry policy and marketization to think of the possible explanation from the external policy environment $[103,117]$. We include a dummy variable (industry policy) equal to 1 if the firm operated in the encouraging industry in the specific host country, otherwise 0. Moreover, prior entry mode studied by Xie [87], who has paid close attention to the impact of the degree of marketization in a firm's local economy. To account for this effect, we incorporate a measure of region-specific marketization. The definition of the marketization is the marketization development level of a regional [128].

In addition, we consider the psychic distance, multidimensional proximity, ownership structure and stock-listed to include the possible explanation from the institution-based view. In this study, the psychic distance is defined as the distance between the home country and the host country which is a factor preventing or disturbing the flow of information between enterprises and markets. We use the absolute differences regarding the level of industrialization, education, language, religion and political systems [101,129]. In addition, we introduce the dummy variables institutional proximity, language proximity, nature proximity, geographic proximity, economic proximity $[97,98]$. Based on the study of Ramasamy, Yeung and Laforet [9], the firm ownership structure contains the State-owned Asset Supervision and Administration Commission (SASAC), SOEs affiliated to local governments (SOELGs), and private investors (PI). Prior researchers found that Chinese SOEs prefer low-equity entry modes because they face greater institutional pressures in host countries than Chinese private firms $[9,130]$. The variable of ownership structure is equal to 3 if the Chinese innovative firm is SASAC, 2 for SOELG, and 1 for PI. The status of the listing has a significant positive effect on the firms overseas invest in developing countries. Therefore, we incorporate a dummy variable (stock-listed) that separates listed from non-listed firms (is equal to 1 if listed) [103,131].

Finally, we generated industry dummy and year dummy to control for industry-specific effect and time-specific effect. Because the Chinese government's "Go out and go global" strategy has prioritized OFDI activities for selected industries [73], we included the industry dummy to account for industry heterogeneity. Table 2 displays the measures and data sources of the variables.

\subsection{Empirical Model}

The empirical analysis is divided into two steps. Firstly, we use a non-parametric model to assess the impact of the individual variable (timing) on the probability of the OFDI event of innovative enterprises. This was done with the non-parametric Kaplan-Meier estimator. Secondly, we consider the multivariate factor analysis to evaluate the effect of each variable by using the Logit model and the Cox proportional hazards regression model. The Kaplan-Meier estimator is used to detect the possible significance of variable in duration, while the Cox proportional hazards model confirmed this significance and detected signs of the influence of any analyzed variable, discarding individual significant variables in the Kaplan-Meier estimator.

\subsubsection{Kaplan-Meier Estimator}

The Kaplan-Meier estimator is one of the most widely used in academic research, as it is a non-parametric estimator with extremely few restrictions. Indeed, the only restriction needed to be considered is that the observed firms-if the data are censored-are assumed to have continued behaving the same way as they did until the OFDI event occurred. To apply this model, all observed duration time was ordered from shortest to longest. For each of these periods, we need to know the number of exits and censures produced. For each time, the individual probability of survival function, accumulated over time, was found with the Kaplan-Meier estimator. Using Kaplan-Meier (KM) estimator [132], the unconditional probability of an OFDI event occurring beyond time $t$ is computed as Equation (1).

$$
S\left(t_{j}\right)=\prod_{j=t_{0}}^{t}\left(1-\frac{d_{j}}{n_{j}}\right)
$$


where $d_{j}$ is the number of sample firms who have conducted the OFDI activities in each time interval and $n_{j}$ is the number of sample firms in the probability of OFDI event occurrence.

\subsubsection{Econometric Model}

The selection of internationalization by the entry mode of exporting, joint venture, WOS, or M\&A is modelled as a qualitative problem. A multinomial logit model is specified to estimate the impact of factors on the probability that each of the four alternatives would be chosen. The multinomial logit model allows the influence variables to affect differential odds of choosing one alternative relative to another. Therefore, the coefficient vector is specific to the substitution rather than the chosen firms. Consequently, the specification of the probabilities is computed as Equation (2).

$$
p_{i j}=\exp \left(x_{i j} B_{j}\right) / \sum_{j=1}^{j=4} \exp \left(x_{i j} B_{j}\right)
$$

where $p_{i j}$ is the probability that the $i$ th innovative firm will choose alternative entry mode $j, x_{i j}$ is a vector of variables representing the variables characterizing the $i$ th innovative firm and the $j$ th entry mode, and $B_{j}$ is the vector of coefficients to sum to one, the system of equations are over-identified. The parameters can be estimated by setting the $B$ s of the alternative to 0 . In our model, it stands to reason to use exporting as the baseline case by which to compare the estimated parameters of the other alternatives (joint venture, WOS or M\&A). In this condition, the specification is reduced to Equation (3).

$$
p_{i j}=\exp \left(x_{i j} B_{i j}\right) / 1+\sum_{e=2}^{4} \exp \left(x_{i j} B_{j}\right)
$$

The baseline alternative is specified as Equation (4).

$$
p_{i 1}=1 / 1+\sum_{e=2}^{4} \exp \left(x_{i j} B_{j}\right)
$$

The parameters (Bs) are estimated by maximizing a log-likelihood function using the Newton-Raphson iteration procedure.

\subsubsection{Cox Regression Model}

The Kaplan-Meier estimator allowed a preliminary analysis of the OFDI event occurrence of innovative firms. However, to analyse the influence of variables on the OFDI event occurrence of firms properly, a model was constructed to consider the effect of all the independent variables simultaneously.

To cope with the observed heterogeneity more accurately, a vector $X$ of variables was introduced into the model, where each element represented the feature vector of the firm $i$ at the time $t$. This approach was adjusted using the Cox model, which used the following hazards model specification (see Equation (5)).

$$
h_{i}(t)=h_{0}(t) \times e^{X_{i} \beta}
$$

where the OFDI event probability of occurrence that innovative firm $i$ faces at a time $t$ is multiplicatively proportional to the baseline function $h_{0}(t)$ which is left unspecified and the proportionate factor depends on the set $X$ of explanatory variables. 


\section{Results}

\subsection{Descriptive Statistics}

Table 3 contains descriptive statistics and Pearson correlation results. The average age of innovative firms is 20.57, the average host country experience for the sample is 0.717 , which is very close to 0.76 average host country experience of Chinese firms reported in past studies, e.g., Xie [87]. As may be seen, the average entry speed between any two operations is 741.282 days, although it has a very wide variation range (from 0 to 58.8 years). In total, the average number of operations per firm is 6.13 , with a total of 981 operations made by 156 innovative firms. Among the Pearson correlation coefficients between location choice, entry mode choice, entry speed and all the other variables, the correlation coefficients between psychic distance and location choice $(r=0.491)$ are the largest positive one, while the correlation coefficients between economic proximity and location choice $(\mathrm{r}=-0.522)$ are the largest negative one. For the variable of entry mode choice, the correlation coefficients between technology-seeking and entry mode choice $(r=0.265)$ are the largest positive one, while the correlation coefficients between ownership structure and entry mode choice $(r=-0.302)$ are the largest negative one. For the variable of entry speed, the correlation coefficients between firm age and the entry speed $(r=0.233)$ are the largest positive one, while the correlation coefficients between the international innovation and entry speed $(r=-0.26)$ are the largest negative one. Possible colinearity among the constructs was tested by estimating variance inflation factors (all VIF $<10$ ), and all passed the recommended standards [133]. 
Table 3. Descriptives and correlation matrix ${ }^{a}$.

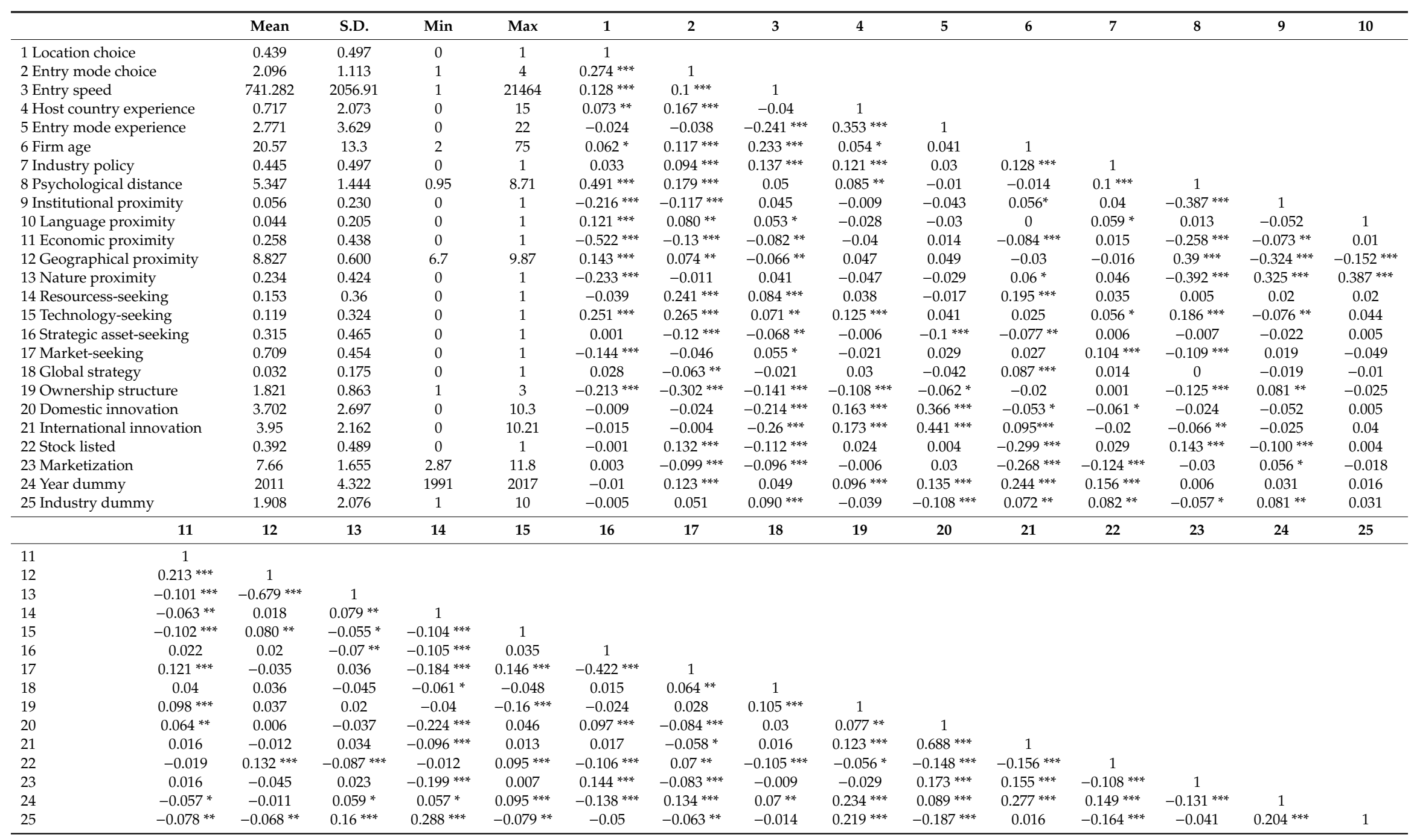

${ }^{\mathrm{a}} \mathrm{n}=981 ;{ }^{* * *} p<0.001 ;{ }^{* *} p<0.01 ;{ }^{*} p<0.05$; two-tailed test. 


\subsection{Kaplan-Meier and Nelson-Aalen Estimators}

We can use the Kaplan-Meier estimator to identify how the probability of market location choice varies across the entry speed. Based on the Kaplan-Meier estimator, we plotted Figure 1 to illustrate the probability of developed countries and developing countries. The figure clearly shows that the Chinese innovative firms are more likely to choose a developing country than a developed country. Both the Log-Rank test-statistic and Wilcoxon test-statistic confirm that difference is statistically significant at the $1 \%$ level.

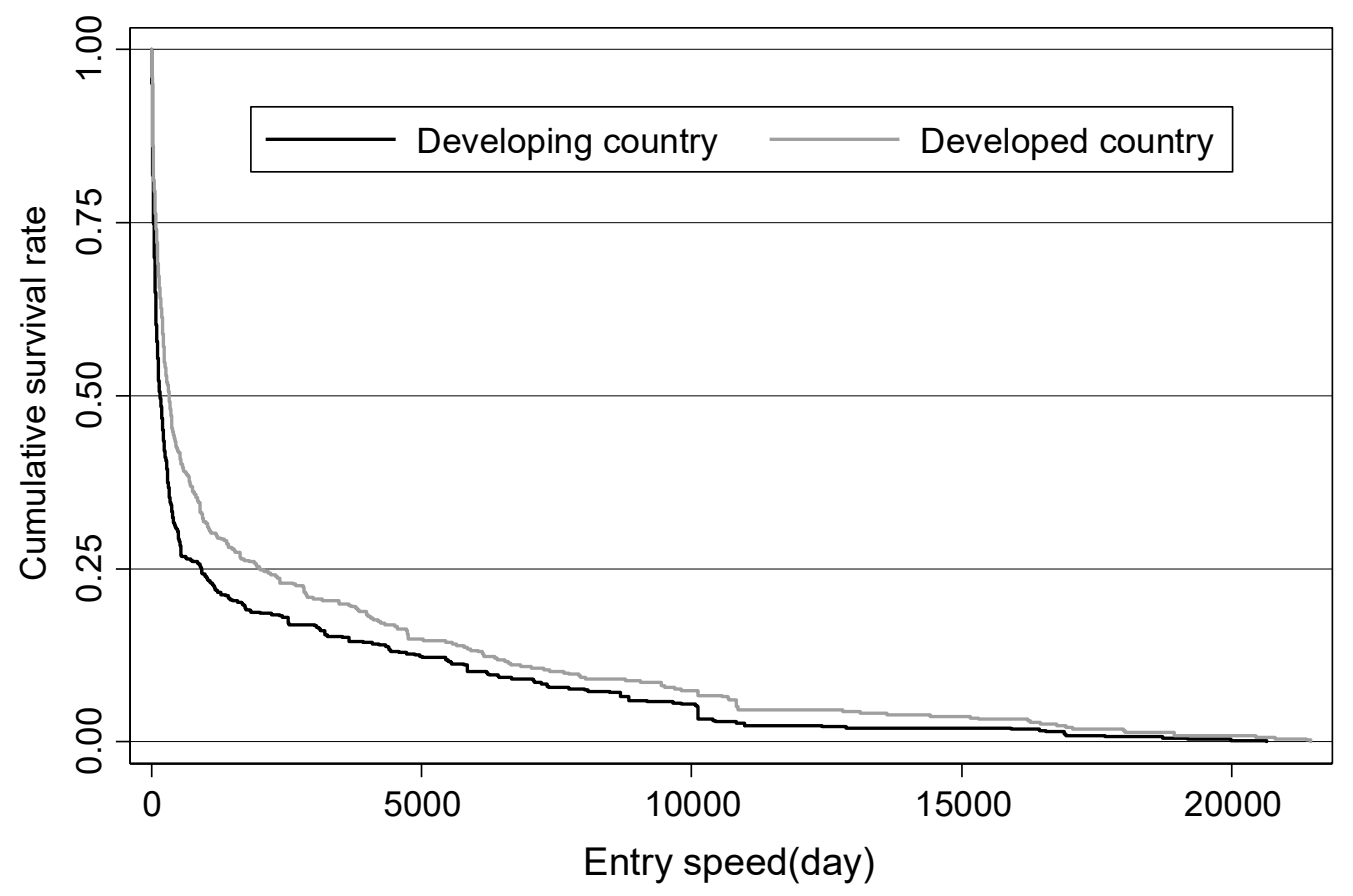

Figure 1. Kaplan-Meier survival function, by location choice.

In addition, in order to analyze the difference of probability for entry mode choice in the developing country and the developed country, we plotted Figures 2 and 3. Figure 2 depicts the Nelson-Aalen cumulative hazard functions for different entry modes of innovative firms to invest in the developed country. Between the entry speed of 17600 days (about 48.21 years) per operation and 1 day per operation, the probability of entry mode choice from high to low in order as acquisition, WOS, exporting and joint venture. Both the Log-Rank test and Wilcoxon test prove that the probability entry mode choice has a significant difference. Furthermore, Figure 3 depicts the Nelson-Aalen cumulative hazard functions of different entry modes of innovative firms in a developing country. The entry mode of exporting has the highest probability and the acquisition has the lowest probability in developing countries at all level of speeds, while the probability of WOS and joint venture are in the middle level. Both the Log-Rank test-statistic and Wilcoxon test-statistic confirm that differences are statistically significant at the $1 \%$ level. 


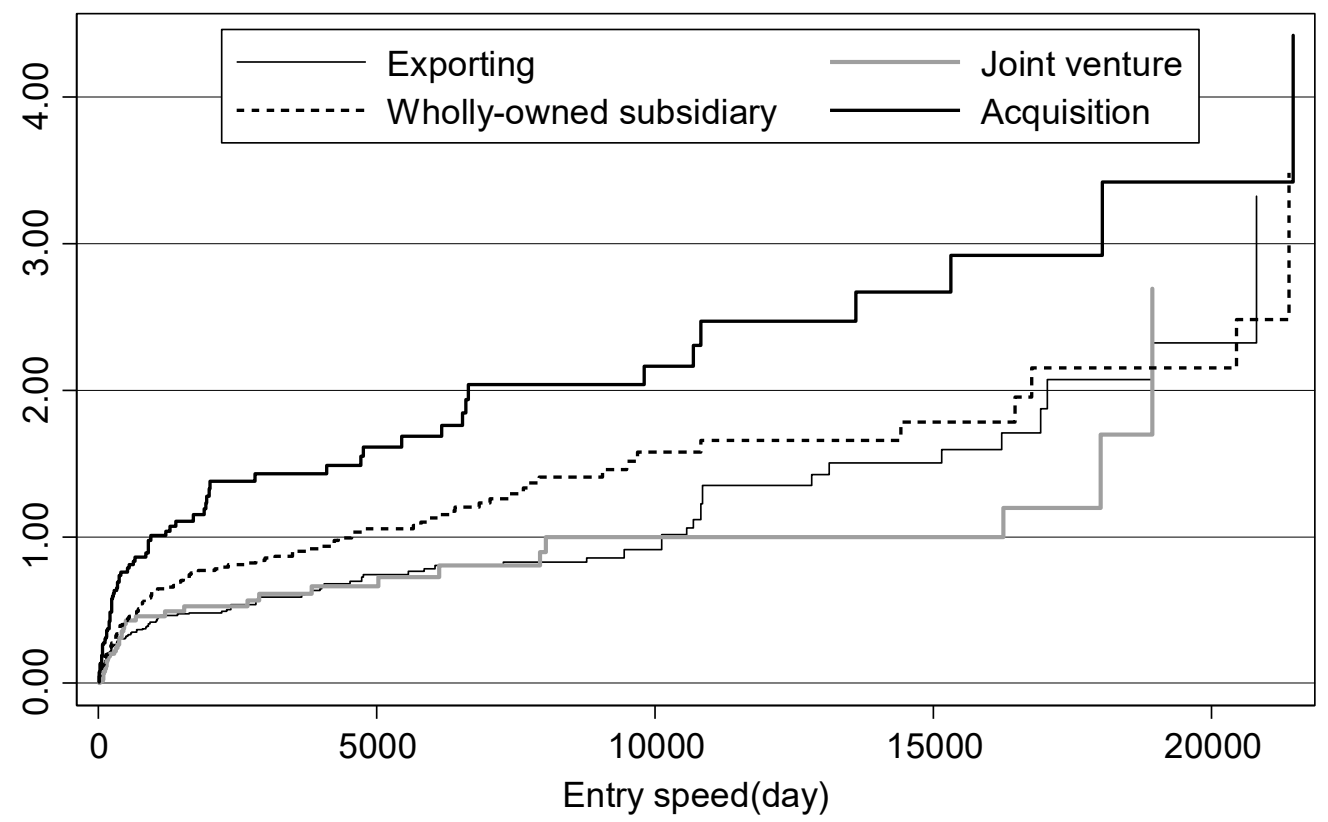

Figure 2. Nelson-Aalen cumulative hazard function, by entry mode in a developed country.

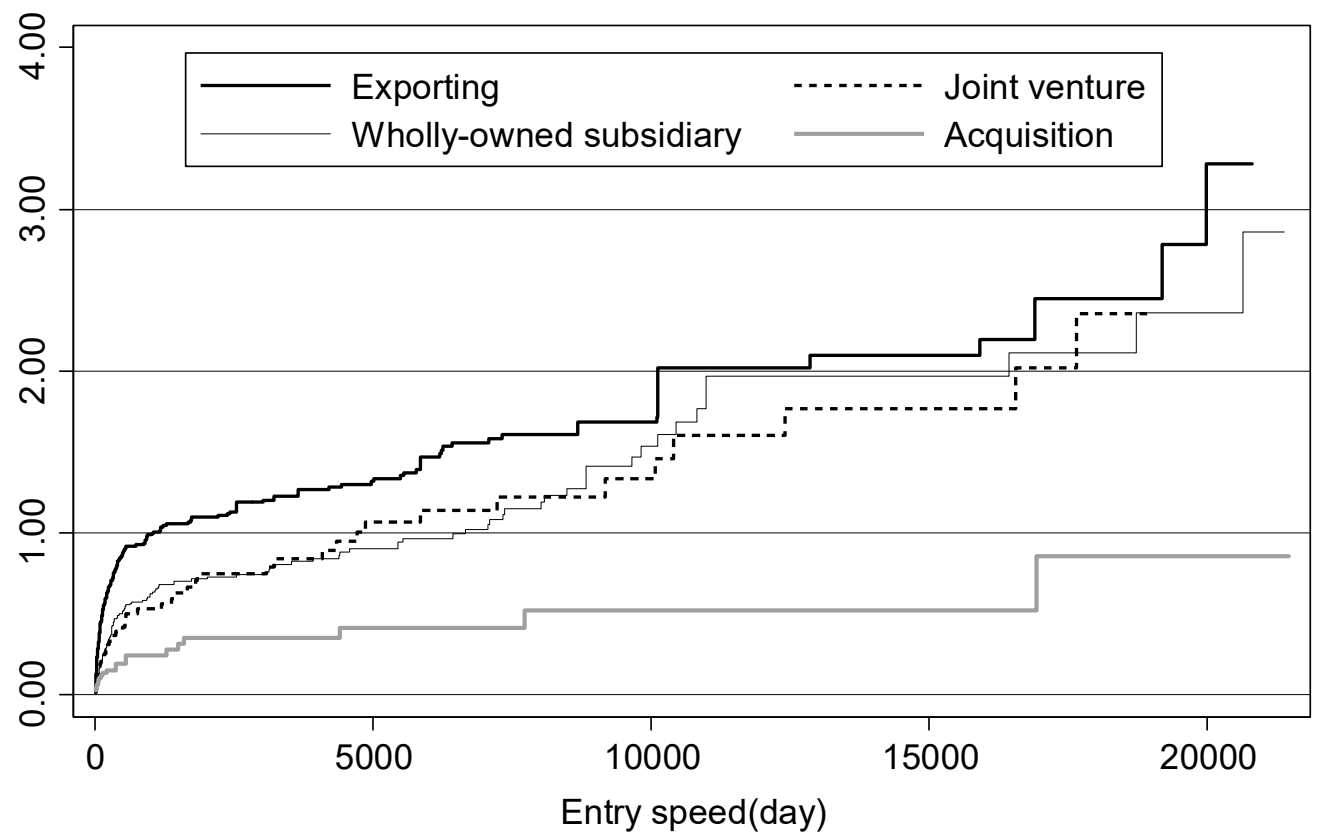

Figure 3. Nelson-Aalen cumulative hazard function, by entry mode in a developing country.

\subsection{Regression Analysis}

Table 4 reports the results of the Logit model for location choice. Model 1 contains all the variables that may have some influence on the MNEs' foreign location choice in the activities of internationalization. Some of the variables have significant effects on foreign location choice. On one hand, the firm age, psychic distance, and the motivation of technology seeking have significant positive effects on the location choice to developed countries. on the other hand, the nature proximity, the ownership structure, the motivation of resource seeking and the motivation of strategic asset seeking have significant positive effects on the location choice to developing countries. Table 4 reports the results of the Multinomial Logit model for entry mode choice. The entry mode of exporting is the base outcome, the host country experience, the motivation of resource seeking and technology seeking, and the stock listed have significant positive effects on the entry mode choice of the joint venture, 
WOS, and acquisition, while the entry mode experience, the motivation of strategic asset seeking and the ownership structure has a significant negative effect on the entry mode choice. Column 2 contains all the variables that may have some influence on the entry mode choice of the joint venture. Moreover, the firm age and nature proximity have significant positive effects on the choice of the joint venture. Column 3 contains all the variables that may have some influence on the entry mode choice of WOS. The language proximity, the geographical proximity, the motivation of market seeking, and the domestic innovation ability have significant positive effects on the entry mode choice of WOS, while the marketization has significant negative effects on the entry mode choice of WOS. Column 4 contains all the variables that may have some influence on the entry mode choice of acquisition. The firm age and the international innovation ability have significant negative effects on the entry mode choice of acquisition, while the economic proximity has significant positive effects on the entry mode choice on the acquisition.

Table 4. Multinomial Logit model for the location choice and entry mode choice.

\begin{tabular}{|c|c|c|c|c|}
\hline \multirow[b]{2}{*}{ Variables } & \multirow{2}{*}{$\begin{array}{c}\text { Developed Country-1 } \\
\text { Developing } \\
\text { Country-0 }\end{array}$} & \multicolumn{3}{|c|}{$\begin{array}{l}\text { Entry Mode Choice } \\
\text { Exporting is the Base Outcome }\end{array}$} \\
\hline & & $\begin{array}{l}\text { Joint Venture } \\
\text { (2) }\end{array}$ & $\begin{array}{l}\text { WOS } \\
(3)\end{array}$ & $\begin{array}{l}\text { Acquisition } \\
\text { (4) }\end{array}$ \\
\hline Host country experience & $\begin{array}{l}-0.013 \\
(0.056)\end{array}$ & $\begin{array}{l}0.315^{* * *} \\
(0.079)\end{array}$ & $\begin{array}{l}0.247^{* * *} \\
(0.062)\end{array}$ & $\begin{array}{l}0.269^{* * *} \\
(0.082)\end{array}$ \\
\hline Entry mode experience & $\begin{array}{l}-0.022 \\
(0.034)\end{array}$ & $\begin{array}{l}-0.114 \text { ** } \\
(0.046)\end{array}$ & $\begin{array}{l}-0.059 * * \\
(0.029)\end{array}$ & $\begin{array}{l}-0.326^{* * *} \\
(0.059)\end{array}$ \\
\hline Firm age & $\begin{array}{l}0.013 \\
(0.009)\end{array}$ & $\begin{array}{l}0.033^{* * *} \\
(0.011)\end{array}$ & $\begin{array}{l}0.006 \\
(0.008)\end{array}$ & $\begin{array}{l}0.029 * * * \\
(0.011)\end{array}$ \\
\hline Policy industry & $\begin{array}{l}0.282 \\
(0.230)\end{array}$ & $\begin{array}{l}-0.071 \\
(0.287)\end{array}$ & $\begin{array}{l}0.177 \\
(0.187)\end{array}$ & $\begin{array}{l}0.158 \\
(0.273)\end{array}$ \\
\hline Psychic distance & $\begin{array}{l}0.340^{* * *} \\
(0.087)\end{array}$ & $\begin{array}{l}0.063 \\
(0.119)\end{array}$ & $\begin{array}{l}-0.011 \\
(0.081)\end{array}$ & $\begin{array}{l}0.126 \\
(0.120)\end{array}$ \\
\hline Institutional proximity & $\begin{array}{l}-18.247 \\
(2612.197)\end{array}$ & $\begin{array}{l}-0.952 \\
(0.767)\end{array}$ & $\begin{array}{l}-0.526 \\
(0.524)\end{array}$ & $\begin{array}{l}-1.030 \\
(1.135)\end{array}$ \\
\hline Language proximity & $\begin{array}{l}17.735 \\
(903.825)\end{array}$ & $\begin{array}{l}0.742 \\
(0.650)\end{array}$ & $\begin{array}{l}1.067^{* *} \\
(0.511)\end{array}$ & $\begin{array}{l}0.419 \\
(0.820)\end{array}$ \\
\hline Economic proximity & $\begin{array}{l}-42.545 \\
(1445.126)\end{array}$ & $\begin{array}{l}-0.362 \\
(0.364)\end{array}$ & $\begin{array}{l}-0.219 \\
(0.224)\end{array}$ & $\begin{array}{l}-1.090^{* * *} \\
(0.420)\end{array}$ \\
\hline Geographical proximity & $\begin{array}{l}0.094 \\
(0.248)\end{array}$ & $\begin{array}{l}0.608 \\
(0.393)\end{array}$ & $\begin{array}{l}0.437^{* *} \\
(0.220)\end{array}$ & $\begin{array}{l}0.448 \\
(0.369)\end{array}$ \\
\hline Nature proximity & $\begin{array}{l}-1.902^{* * *} \\
(0.375)\end{array}$ & $\begin{array}{l}1.358^{* * *} \\
(0.516)\end{array}$ & $\begin{array}{l}0.343 \\
(0.327)\end{array}$ & $\begin{array}{l}-0.151 \\
(0.557)\end{array}$ \\
\hline Resource seeking & $\begin{array}{l}-0.807^{* *} \\
(0.365)\end{array}$ & $\begin{array}{l}1.823^{* * *} \\
(0.436)\end{array}$ & $\begin{array}{l}1.673^{* * *} \\
(0.356)\end{array}$ & $\begin{array}{l}1.999 * * * \\
(0.440)\end{array}$ \\
\hline Technology seeking & $\begin{array}{l}1.506^{* * *} \\
(0.447)\end{array}$ & $\begin{array}{l}1.426^{* * *} \\
(0.481)\end{array}$ & $\begin{array}{l}1.567^{* * *} \\
(0.345)\end{array}$ & $\begin{array}{l}2.107^{* * *} \\
(0.404)\end{array}$ \\
\hline Strategic asset seeking & $\begin{array}{l}-0.498 * \\
(0.272)\end{array}$ & $\begin{array}{l}-0.865^{* *} \\
(0.369)\end{array}$ & $\begin{array}{l}-0.579 * * \\
(0.229)\end{array}$ & $\begin{array}{l}-0.875^{* * *} \\
(0.322)\end{array}$ \\
\hline Market seeking & $\begin{array}{l}-0.426 \\
(0.284)\end{array}$ & $\begin{array}{l}0.551 \\
(0.389)\end{array}$ & $\begin{array}{l}0.438 * \\
(0.258)\end{array}$ & $\begin{array}{l}-0.379 \\
(0.324)\end{array}$ \\
\hline Global strategy & $\begin{array}{l}0.893 \\
(0.737)\end{array}$ & $\begin{array}{l}-1.130 \\
(1.068)\end{array}$ & $\begin{array}{l}-0.765 \\
(0.523)\end{array}$ & $\begin{array}{l}-0.217 \\
(0.742)\end{array}$ \\
\hline Ownership structure & $\begin{array}{l}-0.727^{* * *} \\
(0.139)\end{array}$ & $\begin{array}{l}-0.486^{* * *} \\
(0.185)\end{array}$ & $\begin{array}{l}-0.837^{* * *} \\
(0.123)\end{array}$ & $\begin{array}{l}-0.819^{* * *} \\
(0.201)\end{array}$ \\
\hline Stock listed & $\begin{array}{l}-0.264 \\
(0.252)\end{array}$ & $\begin{array}{l}1.066^{* * *} \\
(0.327)\end{array}$ & $\begin{array}{l}0.463^{* *} \\
(0.215)\end{array}$ & $\begin{array}{l}1.416^{* * *} \\
(0.320)\end{array}$ \\
\hline Marketization & $\begin{array}{l}0.023 \\
(0.073)\end{array}$ & $\begin{array}{l}0.080 \\
(0.091)\end{array}$ & $\begin{array}{l}-0.106^{*} \\
(0.060)\end{array}$ & $\begin{array}{l}0.005 \\
(0.088)\end{array}$ \\
\hline $\begin{array}{l}\text { International innovation } \\
\text { ability }\end{array}$ & $\begin{array}{l}0.082 \\
(0.074)\end{array}$ & $\begin{array}{l}-0.016 \\
(0.095)\end{array}$ & $\begin{array}{l}-0.016 \\
(0.062)\end{array}$ & $\begin{array}{l}0.225^{* *} \\
(0.102)\end{array}$ \\
\hline Domestic innovation ability & $\begin{array}{l}-0.025 \\
(0.060)\end{array}$ & $\begin{array}{l}0.046 \\
(0.074)\end{array}$ & $\begin{array}{l}0.164^{* * *} \\
(0.050)\end{array}$ & $\begin{array}{l}0.053 \\
(0.078)\end{array}$ \\
\hline Constant & $\begin{array}{l}-0.795 \\
(2.262)\end{array}$ & $\begin{array}{l}-8.869 * * \\
(3.627)\end{array}$ & $\begin{array}{l}-3.176 \\
(2.013)\end{array}$ & $\begin{array}{l}-6.204 * \\
(3.281)\end{array}$ \\
\hline Observations & 981 & 981 & 981 & 981 \\
\hline
\end{tabular}

Standard errors in parentheses; ${ }^{* * *} p<0.01,{ }^{* *} p<0.05,{ }^{*} p<0.1$. 
Table 5 reports all the variables that may have some influence on the entry mode choice in developing countries (column 1-3) and in developed countries (column 4-6).

The results of the influence factors on the entry mode choice in developing countries are listed in column 1-3. The host country experience has a significant positive on the choice of the joint venture and WOS (column 1-2), while the entry mode experience has a significant negative effect on the entry mode of acquisition in developing countries (column 3). The motivation of resource seeking and technology seeking have significant positive effects on the entry mode choice in developing countries (column 1-3), while the motivation of strategic asset seeking and the ownership structure have a significant negative effect on the entry mode choice in developing countries (column 1-3). The motivation of market seeking has a significant positive effect on the entry mode of the joint venture and WOS in developing countries (column 1-2). In addition, from the perspective of firm age, ownership structure and stock listed, the firm age has a significant positive effect on the entry mode choice in developing countries (column 1-3), the ownership structure has a significant negative effect on the entry mode choice in developing countries (column 1-3), that means the private enterprises are more likely to choose the WOS and acquisition in developing countries compared with state-owned enterprises. The stock listed firms are more likely to choose the choice of the joint venture and acquisition in developing countries (column 1,3). Finally, the firms' international innovation ability and marketization have significant positive effects on the entry mode of acquisition (column 3), while the domestic innovation ability has a significant positive effect on the entry mode of WOS (column 2). The nature proximity has a significant positive effect on the entry mode of a joint venture (column 1), that means the choice the joint venture entry mode in the host country with the similar religious culture.

The results of the influence factors on the entry mode choice in developed countries are listed in column 4-6. The host country experience and firm age have significant positive effects on the entry mode of joint venture and acquisition in developed countries (column 4, 6), while the entry mode experience has a significant negative effect on the entry mode in developed countries (column 4-6). This result is consistent with Luo and Tung's springboard theory [2]. From the perspective of international motivation. The motivation of resource seeking has a significant negative effect on the entry mode of WOS and acquisition (column 5-6), the motivation of global strategy has a significant positive effect on the entry mode of acquisition (column 6), the motivation of technology seeking has a significant negative effect on the entry mode of acquisition (column 6), while the motivation of market seeking has a significant negative effect on the entry mode choice (column 4-6). The language proximity, economic proximity, and nature proximity have significant positive effects on the entry mode of WOS (column 5), but geographical proximity and nature proximity have significant positive effects on the entry mode of acquisition (column 6). However, the ownership structure has a significant negative effect on the entry of WOS and acquisition (column 5-6). The international innovation ability has a significant positive effect on the entry mode of joint venture and acquisition (column 4,6), while the Domestic innovation ability has a significant negative effect on the entry mode of choice (column 4-6).

Table 6 reports the results of the Cox proportional hazard model for the entry speed. The entry mode experience has a significant negative effect on the entry speed both in developing countries and developed countries, while the firm age has a significant positive effect on the international entry speed, that means the international entry speed is higher for older firms. In addition, the result of column 1 also incorporates the negative linear influence of other variables, such as the motivation of strategic asset seeking, ownership structure, stock listed and international innovation ability on the entry speed in developing countries. The result of column 2 also incorporates the positive linear influence of other variables like policy industry on the entry speed in developed countries, which means these innovative firms have a higher speed of investment in these industries supported by policy from the developed countries' government. Afterwards, the international innovation ability has a negative effect on the entry speed in developed countries. 
Table 5. Multinomial Logit model for the entry mode choice.

\begin{tabular}{|c|c|c|c|c|c|c|}
\hline \multirow[b]{2}{*}{ Variables } & \multicolumn{3}{|c|}{ Exporting is the Base Outcome- in a Developing Country } & \multicolumn{3}{|c|}{ Exporting is the Base Outcome- in a Developed Country } \\
\hline & $\begin{array}{l}\text { Joint Venture } \\
\text { (1) }\end{array}$ & $\begin{array}{c}\text { WOS } \\
\text { (2) }\end{array}$ & $\begin{array}{l}\text { Acquisition } \\
\text { (3) }\end{array}$ & $\begin{array}{l}\text { Joint Venture } \\
\text { (4) }\end{array}$ & $\begin{array}{c}\text { WOS } \\
\text { (5) }\end{array}$ & $\begin{array}{l}\text { Acquisition } \\
\text { (6) }\end{array}$ \\
\hline Host country experience & $\begin{array}{c}0.431^{* * *} \\
(0.133)\end{array}$ & $\begin{array}{c}.392 * * * \\
(0.098)\end{array}$ & $\begin{array}{c}0.121 \\
(0.265)\end{array}$ & $\begin{array}{l}0.244^{* *} \\
(0.105)\end{array}$ & $\begin{array}{c}0.134 \\
(0.083)\end{array}$ & $\begin{array}{l}0.217^{* *} \\
(0.100)\end{array}$ \\
\hline Entry mode experience & $\begin{array}{l}-0.080 \\
(0.064)\end{array}$ & $\begin{array}{l}-0.030 \\
(0.045)\end{array}$ & $\begin{array}{c}-0.401 * * * \\
(0.142)\end{array}$ & $\begin{array}{c}-0.146^{* *} \\
(0.073)\end{array}$ & $\begin{array}{c}-0.072 * \\
(0.043)\end{array}$ & $\begin{array}{c}-0.306^{* * *} \\
(0.070)\end{array}$ \\
\hline Firm age & $\begin{array}{l}0.036 * * \\
(0.018)\end{array}$ & $\begin{array}{l}0.024^{*} \\
(0.012)\end{array}$ & $\begin{array}{l}0.051 * \\
(0.028)\end{array}$ & $\begin{array}{l}0.032 \text { ** } \\
(0.016)\end{array}$ & $\begin{array}{l}-0.012 \\
(0.012)\end{array}$ & $\begin{array}{l}0.022 * \\
(0.013)\end{array}$ \\
\hline Policy industry & $\begin{array}{l}-0.154 \\
(0.413)\end{array}$ & $\begin{array}{c}0.133 \\
(0.278)\end{array}$ & $\begin{array}{l}-0.605 \\
(0.612)\end{array}$ & $\begin{array}{c}0.090 \\
(0.478)\end{array}$ & $\begin{array}{c}0.412 \\
(0.298)\end{array}$ & $\begin{array}{c}0.223 \\
(0.366)\end{array}$ \\
\hline Psychic distance & $\begin{array}{l}-0.118 \\
(0.183)\end{array}$ & $\begin{array}{l}-0.151 \\
(0.136)\end{array}$ & $\begin{array}{l}-0.616^{*} \\
(0.316)\end{array}$ & $\begin{array}{c}0.228 \\
(0.218)\end{array}$ & $\begin{array}{c}0.095 \\
(0.124)\end{array}$ & $\begin{array}{l}0.275^{*} \\
(0.157)\end{array}$ \\
\hline Institutional proximity & $\begin{array}{l}-1.352 \\
(0.886)\end{array}$ & $\begin{array}{l}-0.603 \\
(0.620)\end{array}$ & $\begin{array}{l}-1.362 \\
(1.391)\end{array}$ & $\begin{array}{l}-1.641 \\
(1.213)\end{array}$ & $\begin{array}{l}-0.692 \\
(0.867)\end{array}$ & $\begin{array}{l}-0.199 \\
(1.416)\end{array}$ \\
\hline Language proximity & $\begin{array}{l}0.760 \\
(1.222)\end{array}$ & $\begin{array}{l}1.125 \\
(0.884)\end{array}$ & $\begin{array}{c}-16.064 \\
(2384.170)\end{array}$ & $\begin{array}{c}1.270 \\
(0.932)\end{array}$ & $\begin{array}{l}0.547^{*} \\
(0.330)\end{array}$ & $\begin{array}{c}0.299 \\
(0.465)\end{array}$ \\
\hline Economic proximity & $\begin{array}{l}-0.143 \\
(0.474)\end{array}$ & $\begin{array}{c}0.021 \\
(0.317)\end{array}$ & $\begin{array}{c}0.451 \\
(0.683)\end{array}$ & $\begin{array}{c}3.934 * * * \\
(1.521)\end{array}$ & $\begin{array}{l}1.702 * * \\
(0.751)\end{array}$ & $\begin{array}{l}-0.212 \\
(1.323)\end{array}$ \\
\hline Geographical proximity & $\begin{array}{c}0.420 \\
(0.533)\end{array}$ & $\begin{array}{c}0.507 \\
(0.343)\end{array}$ & $\begin{array}{l}-0.036 \\
(0.657)\end{array}$ & $\begin{array}{c}0.565 \\
(0.712)\end{array}$ & $\begin{array}{c}0.648 \\
(0.540)\end{array}$ & $\begin{array}{c}1.190^{* *} \\
(0.596)\end{array}$ \\
\hline Nature proximity & $\begin{array}{l}1.157^{*} \\
(0.650)\end{array}$ & $\begin{array}{c}0.401 \\
(0.436)\end{array}$ & $\begin{array}{l}-0.267 \\
(0.832)\end{array}$ & $\begin{array}{c}0.346 \\
(0.617)\end{array}$ & $\begin{array}{c}0.986^{* *} \\
(0.396)\end{array}$ & $\begin{array}{c}1.469 * * * \\
(0.450)\end{array}$ \\
\hline Resource seeking & $\begin{array}{c}2.814^{* * *} \\
(0.640)\end{array}$ & $\begin{array}{c}2.607^{* * *} \\
(0.540)\end{array}$ & $\begin{array}{c}3.066^{* * *} \\
(0.892)\end{array}$ & $\begin{array}{l}-0.400 \\
(0.523)\end{array}$ & $\begin{array}{c}-0.569^{*} \\
(0.333)\end{array}$ & $\begin{array}{l}-0.707^{*} \\
(0.390)\end{array}$ \\
\hline Technology seeking & $\begin{array}{c}3.888^{* * *} \\
(1.034)\end{array}$ & $\begin{array}{c}3.376^{* * *} \\
(0.904)\end{array}$ & $\begin{array}{c}3.770^{* * *} \\
(1.264)\end{array}$ & $\begin{array}{l}-0.083 \\
(0.557)\end{array}$ & $\begin{array}{l}-0.226 \\
(0.357)\end{array}$ & $\begin{array}{l}-0.936 * * \\
(0.403)\end{array}$ \\
\hline Strategic asset seeking & $\begin{array}{c}-1.810 * * * \\
(0.649)\end{array}$ & $\begin{array}{c}-0.7711^{* *} \\
(0.353)\end{array}$ & $\begin{array}{c}-1.472^{*} \\
(0.890)\end{array}$ & $\begin{array}{l}-0.565 \\
(1.221)\end{array}$ & $\begin{array}{l}-0.512 \\
(0.731)\end{array}$ & $\begin{array}{l}-0.049 \\
(0.815)\end{array}$ \\
\hline Market seeking & $\begin{array}{l}1.129^{*} \\
(0.680)\end{array}$ & $1.179 * * * *$ & $\begin{array}{l}0.406 \\
0.8399\end{array}$ & $-0.714^{*}$ & $-0.624 * * *$ & -0.587 ** \\
\hline Global strategy & $\begin{array}{c}-15.588 \\
(2,111.196)\end{array}$ & $\begin{array}{l}-1.108 \\
(0.847)\end{array}$ & $\begin{array}{c}-14.767 \\
(2455.189)\end{array}$ & $\begin{array}{c}0.691 \\
(0.503)\end{array}$ & $\begin{array}{c}0.472 \\
(0.316)\end{array}$ & $\begin{array}{c}1.314 * * * \\
(0.400)\end{array}$ \\
\hline Ownership structure & $\begin{array}{c}-0.502 * * \\
(0.246)\end{array}$ & $\begin{array}{c}-0.942 * * * \\
(0.173)\end{array}$ & $\begin{array}{c}-0.834 * * \\
(0.401)\end{array}$ & $\begin{array}{l}-0.055 \\
(0.139)\end{array}$ & $\begin{array}{c}-0.241 * * * \\
(0.091)\end{array}$ & $\begin{array}{c}-0.196^{*} \\
(0.111)\end{array}$ \\
\hline Stock listed & $\begin{array}{c}1.366^{* * *} \\
(0.499)\end{array}$ & $\begin{array}{c}0.516 \\
(0.337)\end{array}$ & $\begin{array}{c}2.476^{* * *} \\
(0.787)\end{array}$ & $\begin{array}{c}0.181 \\
(0.153)\end{array}$ & $\begin{array}{c}0.014 \\
(0.097)\end{array}$ & $\begin{array}{c}0.143 \\
(0.127)\end{array}$ \\
\hline Marketization & $\begin{array}{c}0.177 \\
(0.142)\end{array}$ & $\begin{array}{c}0.030 \\
(0.093)\end{array}$ & $\begin{array}{l}0.432 * \\
(0.227)\end{array}$ & $\begin{array}{l}-0.119 \\
(0.121)\end{array}$ & $\begin{array}{l}0.133^{*} \\
(0.078)\end{array}$ & $\begin{array}{c}0.054 \\
(0.101)\end{array}$ \\
\hline International innovation ability & $\begin{array}{l}-0.125 \\
(0.135)\end{array}$ & $\begin{array}{l}-0.036 \\
(0.091)\end{array}$ & $\begin{array}{l}0.562 * * \\
(0.255)\end{array}$ & $\begin{array}{l}0.244^{* *} \\
(0.105)\end{array}$ & $\begin{array}{c}0.134 \\
(0.083)\end{array}$ & $\begin{array}{l}0.217^{* *} \\
(0.100)\end{array}$ \\
\hline Domestic innovation ability & $\begin{array}{c}0.156 \\
(0.107)\end{array}$ & $\begin{array}{c}0.215^{* * *} \\
(0.073)\end{array}$ & $\begin{array}{c}0.160 \\
(0.165)\end{array}$ & $\begin{array}{l}-0.1466^{* *} \\
(0.073)\end{array}$ & $\begin{array}{c}-0.072 * \\
(0.043)\end{array}$ & $\begin{array}{c}-0.306 * * * * \\
(0.070)\end{array}$ \\
\hline Constant & $\begin{array}{l}-7.880 \\
(5.035)\end{array}$ & $\begin{array}{l}-5.495 * \\
(3.184)\end{array}$ & $\begin{array}{l}-5.976 \\
(6.458)\end{array}$ & $\begin{array}{l}-14.010^{*} \\
(8.13)\end{array}$ & $\begin{array}{l}-3.003 \\
(2.966)\end{array}$ & $\begin{array}{l}-3.324 \\
(4.088)\end{array}$ \\
\hline Observations & 471 & & $\begin{array}{c}0.406) \\
471\end{array}$ & $\begin{array}{c}1.104 \\
426\end{array}$ & 426 & 426 \\
\hline
\end{tabular}

Standard errors in parentheses ${ }^{* * *} p<0.01,{ }^{* *} p<0.05,{ }^{*} p<0.1$. 
Table 6. Empirical results-Cox-hazard regression model. (the entry speed).

\begin{tabular}{|c|c|c|}
\hline Variables & $\begin{array}{c}\text { Developing Country } \\
\text { (1) }\end{array}$ & $\begin{array}{c}\text { Developed Country } \\
\text { (2) }\end{array}$ \\
\hline Host country experience & $\begin{array}{l}-0.045 \\
(0.029)\end{array}$ & $\begin{array}{c}0.020 \\
(0.023)\end{array}$ \\
\hline Entry mode experience & $\begin{array}{c}0.083^{* * *} \\
(0.016)\end{array}$ & $\begin{array}{c}0.059 * * * \\
(0.015)\end{array}$ \\
\hline Firm age & $\begin{array}{c}-0.030 * * * \\
(0.005)\end{array}$ & $\begin{array}{c}-0.033^{* * *} \\
(0.005)\end{array}$ \\
\hline Policy industry & $\begin{array}{l}-0.135 \\
(0.100)\end{array}$ & $\begin{array}{c}-0.193 * \\
(0.111)\end{array}$ \\
\hline Institutional proximity & $\begin{array}{c}0.074 \\
(0.047)\end{array}$ & $\begin{array}{l}-0.080 \\
(0.049)\end{array}$ \\
\hline Language proximity & $\begin{array}{l}-0.146 \\
(0.206)\end{array}$ & $\begin{array}{c}0.172 \\
(0.145)\end{array}$ \\
\hline Economic proximity & $\begin{array}{c}0.460 \\
(0.337)\end{array}$ & $\begin{array}{c}0.022 \\
(0.320)\end{array}$ \\
\hline Geographical proximity & $\begin{array}{l}-0.073 \\
(0.118)\end{array}$ & $\begin{array}{c}0.094 \\
(0.248)\end{array}$ \\
\hline Nature proximity & $\begin{array}{c}0.148 \\
(0.124)\end{array}$ & $\begin{array}{l}-0.022 \\
(0.125)\end{array}$ \\
\hline Psychic distance & $\begin{array}{c}0.237 \\
(0.156)\end{array}$ & $\begin{array}{l}-0.330 \\
(0.286)\end{array}$ \\
\hline Resource seeking & $\begin{array}{l}-0.143 \\
(0.177)\end{array}$ & $\begin{array}{l}-0.032 \\
(0.192)\end{array}$ \\
\hline Technology seeking & $\begin{array}{l}-0.173 \\
(0.236)\end{array}$ & $\begin{array}{l}-0.144 \\
(0.134)\end{array}$ \\
\hline Strategic asset seeking & $\begin{array}{c}0.322 \text { ** } \\
(0.132)\end{array}$ & $\begin{array}{l}-0.048 \\
(0.122)\end{array}$ \\
\hline Market seeking & $\begin{array}{l}-0.224 \\
(0.142)\end{array}$ & $\begin{array}{l}-0.021 \\
(0.126)\end{array}$ \\
\hline Global strategy & $\begin{array}{c}0.033 \\
(0.297)\end{array}$ & $\begin{array}{c}0.180 \\
(0.274)\end{array}$ \\
\hline Ownership structure & $\begin{array}{c}0.299^{* * * *} \\
(0.062)\end{array}$ & $\begin{array}{c}0.026 \\
(0.084)\end{array}$ \\
\hline Stock listed & $\begin{array}{c}0.336^{* * *} \\
(0.121)\end{array}$ & $\begin{array}{c}0.110 \\
(0.123)\end{array}$ \\
\hline Marketization & $\begin{array}{c}0.047 \\
(0.035)\end{array}$ & $\begin{array}{l}-0.026 \\
(0.033)\end{array}$ \\
\hline International innovation ability & $\begin{array}{l}0.109 * * * \\
(0.033)\end{array}$ & $\begin{array}{c}0.057 \\
(0.037)\end{array}$ \\
\hline Domestic innovation ability & $\begin{array}{l}-0.036 \\
(0.027)\end{array}$ & $\begin{array}{c}0.052 \\
(0.033)\end{array}$ \\
\hline Log likelihood & -2839.089 & -2318.751 \\
\hline Chi2 & $181.52 * * *$ & $99.83^{* * *}$ \\
\hline Observations & 550 & 431 \\
\hline
\end{tabular}

Standard errors in parentheses; ${ }^{* * *} p<0.01,{ }^{* *} p<0.05,{ }^{*} p<0.1$.

\section{Discussion and Conclusions}

Drawing on international process theory, we develop a three aspect (entry mode, market location and entry speed) to analyze the path of internationalization of innovative firms, and to explain how factors influence the choice of internationalization path made by innovative firms to invest abroad. Using OFDI event information by Chinese innovative firms over a twenty-seven year period, we find that: (1) Chinese innovative firms are more likely to choose a developing country than a developed country, (2) investing in developed countries, the probability of entry mode choice of innovative firms from high to low is acquisition, wholly-owned subsidiaries, export and joint venture, (3) investing 
in developing countries, the entry mode of export is most likely and acquisition is least likely to be chosen, and (4) this tendency and path of internationalization of choice in entry mode, market location and entry speed are influenced by the international experience, firm age, multidimensional proximity, psychical distance, internationalization motivation, ownership structure, marketization, listed stock and innovation ability. Below, we discuss our contributions to the literature on international process literature and EMNEs internationalization literature.

\subsection{Contributions}

The purpose of this study was to elucidate the paths of internationalization of Chinese innovative enterprises and explore the influencing factors. Our contributions are as follows:

First, our study contributes to the EMNEs' internationalization process literature by distilling the specific knowledge types of international paths. The paths of internationalization are a complicated phenomenon, but a considerable amount of literature about Chinese firms in the field has focused on understanding only one or two dimensions (entry mode, market location, or entry speed) $[13,20$, $73,94,134]$, leaving how Chinese firms choose the paths quite underresearched. Our work defines the paths of internationalization by the three dimensions simultaneously, and its main novelty is the incorporation of speed as an explicit dimension in the study of internationalizing processes. Following this approach, we propose different portfolio for the paths of internationalization: (1) entry mode choice, (2) market location choice, (3) market location and entry mode choice, (4) entry speed and market location choice, (5) entry speed and entry mode choice.

Second, our study also shows the influence of international motivation on the choice of paths of internationalization. (1), for the market location choice, we have found that these innovative firms that have the international motivation of resource-seeking and strategic asset seeking prefer to expand investment activities in developing countries, while the innovative firms that have the international motivation of technology-seeking would prefer to expand their business to developed countries. In addition, the nature proximity is a significant influence factor in location choice. (2), for the entry mode choice, we have found that these innovative firms that have the innovation ability, the motivation to seek resources, market, and technology would more likely choose the entry mode of greenfield investment and acquisition. The listed corporates and private enterprises would more likely choose the entry mode of greenfield investment and acquisition. This result is effective for the host countries of developing countries but is not found in developed countries.

Third, our study also shows the importance of international experience in the process of internationalization. On the one hand, for Chinese innovative firms, the more host country experience they have, the greater the probability to choose the greenfield investment in that country. On the other hand, our study also found these Chinese innovative firms that implement the foreign acquisition activities not based on the entry mode experience, and this finding is logically consistent with the springboard theory of Luo and Tung [17]. Moreover, the entry mode experience would decelerate the internationalization, but this tendency not found for the host country experience.

In addition, our study has defined the number of factors behind the choice of market strategy and location. We introduce the multidimensional proximity in our study, and the result shows that the language proximity, geographical proximity, economic proximity and the nature proximity have a significant positive effect on the entry mode choice of greenfield investment. This result is more effective for these firms that go to developed countries but not developing countries. However, multidimensional proximity has no significant effect on the entry speed of internationalization.

Furthermore, our study enhances the knowledge-based perspective within the EMNEs internationalization literature by showing that the choice of paths of internationalization is driven by firms' international innovation ability and domestic innovation ability. For a long time, innovation ability has always been considered the main source of competitive advantage. Moreover, it draws attention from the researchers of the IB field, but previous research mainly discussed the improving relationship between the internationalization process and the enterprise's innovation $[135,136]$. Whether 
the enterprise's innovation ability has an impact on the enterprises' path of internationalization is still an uncertain theoretical gap [137]. By adopting the knowledge-based perspective in the study of MNEs' international process, we provide new insights into the relationship between the innovation ability and paths of internationalization. In doing so, we reveal the influence of MNEs' international innovation ability and domestic innovation ability on the entry mode choice, market location choice and entry speed.

Finally, our study mitigated the paucity of research regarding studies situated at innovative enterprises by adopting an interpretive approach in EMNEs' internationalization.

\subsection{Managerial Implications}

Along with the academic contributions, our findings also offer valuable guidelines for globally-focused managers from emerging economies who aim to enhance development through internationalization.

First, the current state shows that Chinese innovative firms would more likely choose developing countries than developed countries [138]. This result is in accordance with the vision and action of the Belt and Road policy, in which investment and trade cooperation is a "major task" and the 60 or so countries in Asia, Europe and Africa along the Belt and Road are likely to be the initiative's priority targets of investment. Although the host country from some developing economies may facilitate resource, policymakers should realize that Chinese MNEs need to identify cutting-edge technology when expanding overseas.

Second, our study proves that the probability of entry mode choice has a significant difference in developing countries and developed countries. Therefore, our study suggests that EMNEs should choose the entry mode of export or greenfield investment in developing countries and should choose the entry mode of greenfield investment or acquisition in developed countries.

Further, EME managers should realize that they do not always need to seek strong institutions when expanding overseas but instead, they should look for countries with a high psychic distance to their home countries if their firms have the international motivation for seeking technology. While their firms have the motivation to seek market and resources through the process of internationalization, they could expand their business region to developing countries. Besides, these MNEs could choose the entry mode of greenfield investment in the host country with high language proximity, geographical proximity, economic proximity and nature proximity.

\subsection{Limitations and Future Research}

The present findings have limitations that may guide further research.

Firstly, as is the case with many other studies of firm internationalization, the dataset consists mainly of innovative enterprise. Therefore, the analysis excludes firms that completely failed or non-innovative companies during the period analyzed. The innovative enterprise was evaluated between the years 2008 and 2011. This first limitation calls for future research on the comprehensive assessment of innovation capabilities. An important first step would probably be to analyze this question in depth using qualitative case studies. Moreover, a relevant sample would be the investigation of paths of internationalization of innovative enterprises and other enterprises.

Secondly, with the panel data of enterprises' outward FDI for the internationalization, we employed a well-accepted but aggregated measurement as a proxy. For future research, it would be interesting to provide a systematic, in-depth analysis of the different paths of internationalization to gain a deeper understanding of the internationalization process. Furthermore, we were not able to capture the selection of paths of internationalization in a dynamic way.

A third and related limitation of this paper relates to potential endogeneity [139] among the concepts under examination. It is reasonable to expect the innovation ability to be somewhat influenced by the firm's internationalization. Future studies, however, could further compensate for potential endogeneity bias by including more measurement points of the variables. An alternative idea would be to conduct further in-depth qualitative research on the paths of internationalization. Such approaches 
would also be highly relevant in addressing an interesting avenue for future research on changes in the paths of enterprises' internationalization.

Finally, there are other multiple theoretical perspectives to research the paths of internationalization of Chinese MNEs, such as the perspective of the global value chains (GVC). Participating in the international market competition by the embedding of GVC is the main way for the DMNEs to integrate global resources and build international competitiveness. It is also an important strategy for Chinese MNEs to participate in the international division of labor and achieve internationalization. However, our study has discussed the paths of internationalization basing on a macro perspective (the entry mode, the market location, and the entry speed). Our future research should further study the paths of the MNEs' internationalization basing on the theoretical perspective of GVC, and specifically, explore the path of MNEs' internationalization by studying the embedding mode of GVC.

Author Contributions: L.M. and H.D. designed the research and wrote the manuscript. H.D., L.M., and N.W. made contribution to the analysis of the results. All authors have read and agreed to the published version of the manuscript.

Funding: This paper was funded by National Natural Science Foundation of China (Grant No. 71974136), the PHC Cai Yuanpei project and that of the China Scholarship Council (CSC) (201700260120). The financial support is gratefully acknowledged.

Conflicts of Interest: The authors declare no conflicts of interest.

\section{References}

1. Chee, H.; Harris, R. Global Marketing Strategy; Financial Times Pitman Pub.: New York, NY, USA, 1998; pp. 319-331.

2. Luo, Y.; Tung, R.L. International expansion of emerging market enterprises: A springboard perspective. J. Int. Bus. Stud. 2007, 38, 481-498. [CrossRef]

3. Swaine, M.D. Chinese views and commentary on the 'One Belt, One Road'initiative. China Leadersh. Monit. $2015,47,3$.

4. United Nations Conference on Trade and Development (UNCTAD). World Investment Report 2016: Investment and the Digital Economy; The United Nations: Geneva, Switzerland, 2017; pp. 1-5.

5. Ramamurti, R. What is really different about emerging market multinationals? Glob. Strategy J. 2012, 2, 41-47. [CrossRef]

6. Kotabe, M.; Kothari, T. Emerging market multinational companies' evolutionary paths to building a competitive advantage from emerging markets to developed countries. J. World Bus. 2016, 51, 729-743. [CrossRef]

7. Mathews, J.A. Dragon multinationals: New players in 21st century globalization. Asia Pac. J. Manag. 2006, 23, 5-27. [CrossRef]

8. Jansson, H.; Söderman, S. Initial internationalization of Chinese privately owned enterprises-The take-off process. Thunderbird Int. Bus. Rev. 2012, 54, 183-194. [CrossRef]

9. Ramasamy, B.; Yeung, M.; Laforet, S. China's outward foreign direct investment: Location choice and firm ownership. J. World Bus. 2012, 47, 17-25. [CrossRef]

10. Cui, L.; Jiang, F. FDI entry mode choice of Chinese firms: A strategic behavior perspective. J. World Bus. 2009, 44, 434-444. [CrossRef]

11. Buckley, P.J.; Cross, A.R.; Tan, H.; Xin, L.; Voss, H. Historic and emergent trends in Chinese outward direct investment. Manag. Int. Rev. 2008, 48, 715-748. [CrossRef]

12. Sun, S.L.; Peng, M.W.; Ren, B.; Yan, D. A comparative ownership advantage framework for cross-border M\&As: The rise of Chinese and Indian MNEs. J. World Bus. 2010, 47, 4-16.

13. Anderson, J.; Sutherland, D. Entry mode and emerging market MNEs: An analysis of Chinese greenfield and acquisition FDI in the United States. Res. Int. Bus. Financ. 2015, 35, 88-103. [CrossRef]

14. Santangelo, G.D.; Meyer, K.E. Internationalization as an evolutionary process. J. Int. Bus. Stud. 2017, 48, 1114-1130. [CrossRef]

15. Ramamurti, R.; Hillemann, J. What is "Chinese" about Chinese multinationals? J. Int. Bus. Stud. 2018, 49, 34-48. [CrossRef] 
16. Dominguez, N.; Mayrhofer, U. Internationalization stages of traditional SMEs: Increasing, decreasing and re-increasing commitment to foreign markets. Int. Bus. Rev. 2017, 26, 1051-1063. [CrossRef]

17. Luo, Y.; Tung, R.L. A general theory of springboard MNEs. J. Int. Bus. Stud. 2018, 49, 129-152. [CrossRef]

18. Madhok, A.; Keyhani, M. Acquisitions as entrepreneurship: Asymmetries, opportunities, and the internationalization of multinationals from emerging economies. Glob. Strategy J. 2012, 2, 26-40. [CrossRef]

19. Cuervo-Cazurra, A.; Luo, Y.D.; Ramamurti, R.; Ang, S.H. The Impact of the home country on internationalization. J. World Bus. 2018, 53, 593-604. [CrossRef]

20. Elia, S.; Santangelo, G.D. The evolution of strategic asset-seeking acquisitions by emerging market multinationals. Int. Bus. Rev. 2017, 26, 855-866. [CrossRef]

21. Wei, Y.; Zheng, N.; Liu, X.; Lu, J. Expanding to outward foreign direct investment or not? A multi-dimensional analysis of entry mode transformation of Chinese private exporting firms. Int. Bus. Rev. 2014, 23, 356-370. [CrossRef]

22. Li, X.; Quan, R.; Stoian, M.-C.; Azar, G. Do MNEs from developed and emerging economies differ in their location choice of FDI? A 36-year review. Int. Bus. Rev. 2018, 27, 1089-1103. [CrossRef]

23. Casillas, J.C.; Moreno-Menendez, A.M. Speed of the internationalization process: The role of diversity and depth in experiential learning. J. Int. Bus. Stud. 2014, 45, 85-101. [CrossRef]

24. Schumpeter, J.A. The Theory of Economic Development: An Inquiry into Profits, Capital, Credit, Interest, and the Business Cycle; Transaction Publishers: New Jersey, NJ, USA, 1934; p. 55.

25. Freeman, C. The Economics of Industrial Innovation, 2nd ed.; MIT Press: Cambridge, UK, 1982; p. 250.

26. LeFebvre, L.A.; LeFebvre, E. The innovative business firm in Canada: An empirical study of CAD/CAM firms. Int. Lab. Rev. 1988, 127, 497.

27. Lumpkin, G.T.; Dess, G.G. Clarifying the entrepreneurial orientation construct and linking it to performance. Acad. Manag. Rev. 1996, 21, 135-172. [CrossRef]

28. OECD/Eurostat. The Measurement of Scientific and Technological Activities: Guidelines for Collecting and Interpreting Innovation Data, 3rd ed.; OECD Publishing: Paris, France, 2005.

29. Pigato, M. Promoting Enterprise-Led Innovation in China; The World Bank: Washington, DC, USA, 2009.

30. Johanson, J.; Vahlne, J.-E. The internationalization process of the firm-a model of knowledge development and increasing foreign market commitments. J. Int. Bus. Stud. 1977, 8, 23-32. [CrossRef]

31. Johanson, J.; Vahlne, J.-E. The mechanism of internationalisation. Int. Mark. Rev. 1990, 7, 23-32. [CrossRef]

32. Buckley, P.J.; Casson, M. The Future of the Multinational Enterprise; Springer: New York, NY, USA, 2016.

33. Dunning, J.H. The eclectic paradigm of international production: A restatement and some possible extensions. J. Int. Bus. Stud. 1988, 19, 1-31. [CrossRef]

34. Liu, X.; Buck, T. Innovation performance and channels for international technology spillovers: Evidence from Chinese high-tech industries. Res. Policy 2007, 36, 355-366. [CrossRef]

35. Gorodnichenko, Y.; Svejnar, J.; Terrell, K. Globalization and Innovation in Emerging Markets; The World Bank: Washington, DC, USA, 2009.

36. Wu, J.; Wang, C.Q.; Hong, J.J.; Piperopoulos, P.; Zhuo, S.H. Internationalization and innovation performance of emerging market enterprises: The role of host-country institutional development. J. World Bus. 2016, 51, 251-263. [CrossRef]

37. Tian, X.; Wang, T.Y. Tolerance for failure and corporate innovation. Rev. Financ. Stud. 2011, 27, $211-255$. [CrossRef]

38. Kwok, C.C.; Reeb, D.M. Internationalization and firm risk: An upstream-downstream hypothesis. J. Int. Bus. Stud. 2000, 31, 611-629. [CrossRef]

39. Felicio, J.A.; Caldeirinha, V.R.; Ribeiro-Navarrete, B. Corporate and individual global mind-set and internationalization of European SMEs. J. Bus. Res. 2015, 68, 797-802. [CrossRef]

40. Yang, W. National Natural Science Foundation of China: Funding excellent basic research for 30 years. Nature 2016, 537, 1-5.

41. Chi, T.; Sun, Y. Development of firm export market oriented behavior: Evidence from an emerging economy. Int. Bus. Rev. 2013, 22, 339-350. [CrossRef]

42. Du, J.; Zhang, Y. Does One Belt One Road initiative promote Chinese overseas direct investment? China Econ. Rev. 2018, 47, 189-205. [CrossRef]

43. Ferdinand, P. Westward ho-The China dream and 'one belt, one road': Chinese foreign policy under Xi Jinping. Int. Aff. 2016, 92, 941-957. [CrossRef] 
44. Schwab, K. Emerging Best Practices of Chinese Globalizers: Develop the Innovation Model; World Economic Forum: Geneva, Switzerland, 2015.

45. Luo, Y.; Xue, Q.; Han, B. How emerging market governments promote outward FDI: Experience from China. J. World Bus. 2010, 45, 68-79. [CrossRef]

46. Kim, W.C.; Hwang, P. Global strategy and multinationals' entry mode choice. J. Int. Bus. Stud. 1992, 23, 29-53. [CrossRef]

47. Mohr, A.; Batsakis, G. Internationalization Speed and Firm Performance: A Study of the Market-Seeking Expansion of Retail MNEs. Manag. Int. Rev. 2017, 57, 153-177. [CrossRef]

48. Sakr, M.; Jordaan, A. Emerging Multinationals Corporations: Theoretical and Conceptual Framework; Economic Research Southern Africa: Cape Town, South Africa, 2016; p. 574.

49. Sharma, V.M.; Erramilli, M.K. Resource-based explanation of entry mode choice. J. Mark. Theory Pract. 2004, 12, 1-18. [CrossRef]

50. Ulrich, A.M.D.; Boyd, B.; Hollensen, S. Financial performance of entry mode decisions: Effects of control in an internationalization context. Int. J. Bus. Manag. 2012, 7, 12. [CrossRef]

51. Li, M.; He, X.; Sousa, C.M. A review of the empirical research on export channel selection between 1979 and 2015. Int. Bus. Rev. 2017, 26, 303-323. [CrossRef]

52. Navarro, A.; Acedo, F.J.; Robson, M.J.; Ruzo, E.; Losada, F. Antecedents and consequences of firms' export commitment: An empirical study. J. Int. Mark. 2010, 18, 41-61. [CrossRef]

53. Donthu, N.; Kim, S.H. Implications of firm controllable factors on export growth. J. Glob. Mark. 1993, 7, 47-64. [CrossRef]

54. Navarro-García, A. Drivers of export entrepreneurship. Int. Bus. Rev. 2016, 25, 244-254. [CrossRef]

55. Brady, D.L.; Bearden, W.O. The effect of managerial attitudes on alternative exporting methods. J. Int. Bus. Stud. 1979, 10, 79-84. [CrossRef]

56. Dung, N.V.; Janssen, F. Entrepreneur's actual behavioral controls, psychic distance stimuli, and export mode choice. J. Dev. Entrep. 2015, 20, 1550013-1-1550013-24. [CrossRef]

57. Anderson, P.; Tushman, M.L. Technological discontinuities and dominant designs: A cyclical model of technological change. Adm. Sci. Q. 1990, 8, 604-633. [CrossRef]

58. Yan, A.; Luo, Y. International Joint Ventures: Theory and Practice: Theory and Practice; Routledge: London, UK, 2016; pp. 182-188.

59. Ma, Z.; Yu, M.; Gao, C.; Zhou, J.; Yang, Z. Institutional constraints of product innovation in China: Evidence from international joint ventures. J. Bus. Res. 2015, 68, 949-956. [CrossRef]

60. Colombage, S.R.; Gunasekarage, A.; Shams, S.M. Target's organisational form and returns to A ustralian bidders in cross-border acquisitions. Account. Financ. 2014, 54, 1063-1091. [CrossRef]

61. Larsson, R.; Finkelstein, S. Integrating strategic, organizational, and human resource perspectives on mergers and acquisitions: A case survey of synergy realization. Organ Sci. 1999, 10, 1-26. [CrossRef]

62. Puck, J.; Hödl, M.K.; Filatotchev, I.; Wolff, H.-G.; Bader, B. Ownership mode, cultural distance, and the extent of parent firms' strategic control over subsidiaries in the PRC. Asia Pac. J. Manag. 2016, 33, 1075-1105. [CrossRef]

63. Chung, C.C.; Xiao, S.S.; Lee, J.Y.; Kang, J. The interplay of top-down institutional pressures and bottom-up responses of transition economy firms on FDI entry mode choices. Manag. Int. Rev. 2016, 56, 699-732. [CrossRef]

64. Deng, P. Why do Chinese firms tend to acquire strategic assets in international expansion? J. World Bus. 2009, 44, 74-84. [CrossRef]

65. Chen, R.Y.; Cui, L.; Li, S.L.; Rolfe, R. Acquisition or greenfield entry into africa? responding to institutional dynamics in an emerging continent. Glob. Strategy J. 2017, 7, 212-230. [CrossRef]

66. Amendolagine, V.; Cozza, C.; Rabellotti, R. Chinese and Indian multinationals: A firm-level analysis of their investments in Europe. Glob. Econ. Rev. 2015, 44, 452-469. [CrossRef]

67. Anderson, J.; Sutherland, D.; Severe, S. An event study of home and host country patent generation in Chinese MNEs undertaking strategic asset acquisitions in developed markets. Int. Bus. Rev. 2015, 24, 758-771. [CrossRef]

68. Liou, C.-S. Bureaucratic politics and overseas investment by Chinese state-owned oil companies: Illusory champions. Asian Surv. 2009, 49, 670-690. [CrossRef] 
69. Jain, N.K.; Lahiri, S.; Hausknecht, D.R. Emerging market multinationals' location choice: The role of firm resources and internationalization motivations. Eur. Bus. Rev. 2013, 25, 263-280. [CrossRef]

70. Kalotay, K.; Sulstarova, A. Modelling russian outward FDI. J. Int. Manag. 2010, 16, 131-142. [CrossRef]

71. Cuervo-Cazurra, A. The multinationalization of developing country MNEs: The case of multilatinas. J. Int. Manag. 2008, 14, 138-154. [CrossRef]

72. Gammeltoft, P.; Barnard, H.; Madhok, A. Emerging multinationals, emerging theory: Macro- and micro-level perspectives. J. Int. Manag. 2010, 16, 95-101. [CrossRef]

73. Piperopoulos, P.; Wu, J.; Wang, C. Outward FDI, location choices and innovation performance of emerging market enterprises. Res. Policy 2018, 47, 232-240. [CrossRef]

74. Cuervo-Cazurra, A.; Genc, M. Transforming disadvantages into advantages: Developing country MNEs in the least developed countries. J. Int. Bus. Stud. 2008, 39, 957-979. [CrossRef]

75. Cuervo-Cazurra, A. Sequence of value-added activities in the multinationalization of developing country firms. J. Int. Manag. 2007, 13, 258-277. [CrossRef]

76. Jormanainen, I.; Koveshnikov, C.A. International activities of emerging market firms. Manag. Int. Rev. 2012, 52, 691-725. [CrossRef]

77. Casillas, J.C.; Acedo, F.J. Speed in the internationalization process of the firm. Int. J. Manag. Rev. 2013, 15, 15-29. [CrossRef]

78. Hilmersson, M.; Johanson, M. Speed of SME internationalization and performance. Manag. Int. Rev. 2016, 56, 67-94. [CrossRef]

79. Oviatt, B.M.; McDougall, P.P. Defining international entrepreneurship and modeling the speed of internationalization. Entrep. Theory Pract. 2005, 29, 537-553. [CrossRef]

80. Prashantham, S.; Young, S. Post-entry speed of international new ventures. Entrep. Theory Pract. 2011, 35, 275-292. [CrossRef]

81. Schu, M.; Morschett, D.; Swoboda, B. Internationalization speed of online retailers: A resource-based perspective on the influence factors. Manag. Int. Rev. 2016, 56, 733-757. [CrossRef]

82. Chetty, S.; Johanson, M.; Martín, O.M. Speed of internationalization: Conceptualization, measurement and validation. J. World Bus. 2014, 49, 633-650. [CrossRef]

83. Gao, G.Y.; Pan, Y. The pace of MNEs' sequential entries: Cumulative entry experience and the dynamic process. J. Int. Bus. Stud. 2010, 41, 1572-1580. [CrossRef]

84. Musteen, M.; Francis, J.; Datta, D.K. The influence of international networks on internationalization speed and performance: A study of Czech SMEs. J. World Bus. 2010, 45, 197-205. [CrossRef]

85. Coeurderoy, R.; Murray, G. Regulatory environments and the location decision: Evidence from the early foreign market entries of new-technology-based firms. In Location of International Business Activities; Palgrave Macmillan: London, UK, 2014; pp. 226-260.

86. Luo, Y.; Hongxin Zhao, J.; Du, J. The internationalization speed of e-commerce companies: An empirical analysis. Int. Mark. Rev. 2005, 22, 693-709. [CrossRef]

87. Xie, Q. Firm age, marketization, and entry mode choices of emerging economy firms: Evidence from listed firms in China. J. World Bus. 2017, 52, 372-385. [CrossRef]

88. Xue, Q.; Zheng, Q.; Lund, D.W. The internationalization of service firms in China: A comparative analysis with manufacturing firms. Thunderbird Int. Bus. Rev. 2013, 55, 137-151. [CrossRef]

89. Rienda, L.; Claver, E.; Quer, D. The internationalisation of Indian multinationals: Determinants of expansion through acquisitions. J. Asia. Pac. Econ. 2013, 18, 115-132. [CrossRef]

90. Slangen, A.H.; Hennart, J.-F. Do multinationals really prefer to enter culturally distant countries through greenfields rather than through acquisitions? The role of parent experience and subsidiary autonomy. J. Int. Bus. Stud. 2008, 39, 472-490. [CrossRef]

91. Dow, D.; Larimo, J. Disentangling the roles of international experience and distance in establishment mode choice. Manag. Int. Rev. 2011, 51, 321-355. [CrossRef]

92. Lu, J.; Liu, X.; Filatotchev, I.; Wright, M. The impact of domestic diversification and top management teams on the international diversification of Chinese firms. Int. Bus. Rev. 2014, 23, 455-467. [CrossRef]

93. Gao, L.; Liu, X.; Zou, H. The role of human mobility in promoting Chinese outward FDI: A neglected factor? Int. Bus. Rev. 2013, 22, 437-449. [CrossRef]

94. Xie, E.; Reddy, K.; Liang, J. Country-specific determinants of cross-border mergers and acquisitions: A comprehensive review and future research directions. J. World Bus. 2017, 52, 127-183. [CrossRef] 
95. Buckley, P.J.; Liu, X. The determinants of Chinese outward foreign direct investment. J. Int. Bus. Stud. 2009, 40, 353-354. [CrossRef]

96. Kang, Y.; Jiang, F. FDI location choice of Chinese multinationals in East and Southeast Asia: Traditional economic factors and institutional perspective. J. World Bus. 2012, 47, 45-53. [CrossRef]

97. Boschma, R. Proximity and innovation: A critical assessment. Reg. Stud. 2005, 39, 61-74. [CrossRef]

98. Frigant, V. Between Internationalisation and Proximity: The Internationalisation Process of Automotive First tier Suppliers; Groupe de Recherche en Economie Théorique et Appliquée (GREThA): Pessac, France, 2007; pp. 3-31.

99. Hofstede, G.H.; Hofstede, G. Culture's Consequences: Comparing Values, Behaviors, Institutions and Organizations across Nations; Sage: Southend Oaks, CA, USA, 2001; pp. 9-11.

100. Tihanyi, L.; Griffith, D.A.; Russell, C.J. The effect of cultural distance on entry mode choice, international diversification, and MNE performance: A meta-analysis. J. Int. Bus. Stud. 2005, 36, 270-283. [CrossRef]

101. Blomkvist, K.; Drogendijk, R. The Impact of Psychic Distance on Chinese Outward Foreign Direct Investments. Manag. Int. Rev. 2013, 53, 659-686. [CrossRef]

102. Dow, D.; Karunaratna, A. Developing a multidimensional instrument to measure psychic distance stimuli. J. Int. Bus. Stud. 2006, 37, 578-602. [CrossRef]

103. Wang, C.; Hong, J.; Kafouros, M.; Wright, M. Exploring the role of government involvement in outward FDI from emerging economies. J. Int. Bus. Stud. 2012, 43, 655-676. [CrossRef]

104. Cozza, C.; Rabellotti, R.; Sanfilippo, M. The impact of outward FDI on the performance of Chinese firms. China Econ. Rev. 2015, 36, 42-57. [CrossRef]

105. United Nations Conference on Trade and Development (UNCTAD). World Investment Report 2015: Reforming International Investment Governance; United Nations Publications Customer Service: New York, NY, USA; Geneva, Switzerland, 2015; pp. 78-85.

106. Cheng, L.K.; Ma, Z. China's Outward FDI: Past and Future; Renmin University of China: Beijing, China, 2007; pp. 1-36.

107. Yun, S.Z.; Schüller, M. The internationalization of Chinese companies: What do official statistics tell us about Chinese outward foreign direct investment? Chin. Manag. Stud. 2009, 3, $25-42$.

108. Sutherland, D.; Anderson, J. The pitfalls of using foreign direct investment data to measure Chinese multinational enterprise activity. China Q. 2014, 221, 21-48. [CrossRef]

109. Vareska, V.D.V. Balancing your technology-sourcing portfolio: How sourcing mode diversity enhances innovative performance. Strateg. Manag. J. 2014, 34, 610-621.

110. Gabrielsson, M.; Kirpalani, V.M.; Dimitratos, P.; Solberg, C.A.; Zucchella, A. Born globals: Propositions to help advance the theory. Int. Bus. Rev. 2008, 17, 385-401. [CrossRef]

111. Vermeulen, F.; Barkema, H. Pace, rhythm, and scope: Process dependence in building a profitable multinational corporation. Strateg. Manag. J. 2002, 23, 637-653. [CrossRef]

112. Barkema, H.G.; Vermeulen, F. International expansion through start-up or acquisition: A learning perspective. Acad. Manag. J. 1998, 41, 7-26.

113. Li, P.Y.; Meyer, K.E. Contextualizing experience effects in international business: A study of ownership strategies. SSRN Electron. J. 2009, 44, 370-382. [CrossRef]

114. Hennart, J.-F.; Slangen, A.H. Yes, we really do need more entry mode studies! A commentary on Shaver. J. Int. Bus. Stud. 2015, 46, 114-122. [CrossRef]

115. Padmanabhan, P.; Cho, K.R. Decision specific experience in foreign ownership and establishment strategies: Evidence from Japanese firms. J. Int. Bus. Stud. 1999, 30, 25-43. [CrossRef]

116. Chang, S.J.; Rosenzweig, P.M. The choice of entry mode in sequential foreign direct investment. Strateg. Manag. J. 2001, 22, 747-776. [CrossRef]

117. Lu, J.Y.; Liu, X.H.; Wright, M.; Filatotchev, I. International experience and FDI location choices of Chinese firms: The moderating effects of home country government support and host country institutions. J. Int. Bus. Stud. 2014, 45, 428-449. [CrossRef]

118. Deng, P. Outward investment by Chinese MNCs: Motivations and implications. Bus. Horiz 2004, 47, 8-16. [CrossRef]

119. Kang, Y.; Liu, Y. Natural resource-seeking intent and regulatory forces: Location choice of Chinese outward foreign direct investment in Asia. Manag. Res. Rev. 2016, 39, 1313-1335. [CrossRef] 
120. Yao, S.; Zhang, F.; Wang, P.; Luo, D. Location Determinants of China's Outward Foreign Direct Investment. China World Econ. 2017, 25, 1-27. [CrossRef]

121. Li, J.; Strange, R.; Ning, L.; Sutherland, D. Outward foreign direct investment and domestic innovation performance: Evidence from China. Int. Bus. Rev. 2016, 25, 1010-1019. [CrossRef]

122. Dunning, J.H.; Lundan, S.M. Multinational Enterprises and the Global Economy; Edward Elgar Publishing: Cheltenham, UK, 2008; pp. 48-49.

123. Boateng, A.; Du, M.; Wang, Y.; Wang, C.Q.; Ahammad, M.F. Explaining the surge in M\&A as an entry mode: Home country and cultural influences. Int. Mark. Rev. 2017, 34, 87-108.

124. Wright, M.; Filatotchev, I.; Hoskisson, R.E.; Peng, M.W. Strategy Research in Emerging Economies: Challenging the Conventional Wisdom*. J. Manag. Stud. 2005, 42, 1-33. [CrossRef]

125. Rui, H.; Yip, G.S. Foreign acquisitions by Chinese firms: A strategic intent perspective. J. World Bus. 2008, 43, 213-226. [CrossRef]

126. Hannan, M.T.; Freeman, J. Structural inertia and organizational change. Am. Sociol. Rev. 1984, 49, 149-164. [CrossRef]

127. De Rassenfosse, G.; Dernis, H.; Guellec, D.; Picci, L.; Van Pottelsberghe de la Potterie, B. The worldwide count of priority patents: A new indicator of inventive activity. Res. Policy 2013, 42, 720-737. [CrossRef]

128. Fan, G.; Wang, X.; Zhang, L.; Zhu, H. Marketization Index of China's Provinces: WERI Report 2016; Social Sciences Academic Press: Beijing, China, 2017; pp. 9-18.

129. Magnani, G.; Zucchella, A.; Floriani, D.E. The logic behind foreign market selection: Objective distance dimensions vs. strategic objectives and psychic distance. Int. Bus. Rev. 2018, 27, 1-20. [CrossRef]

130. Cui, L.; Jiang, F. State ownership effect on firms' FDI ownership decisions under institutional pressure: A study of Chinese outward-investing firms. J. Int. Bus. Stud. 2012, 43, 264-284. [CrossRef]

131. Hu, H.W.; Cui, L. Outward foreign direct investment of publicly listed firms from China: A corporate governance perspective. Int. Bus. Rev. 2014, 23, 750-760. [CrossRef]

132. Kalbfleisch, J.D.; Prentice, R.L. The Statistical Analysis of Time Failure Data; John Wiley \& Sons: Hoboken, NJ, USA, 1980; pp. 328-361.

133. Belsley, D.A. On the efficient computation of the nonlinear full-information maximum-likelihood estimator. J. Econ. 1980, 14, 203-225. [CrossRef]

134. Johanson, M.; Kalinic, I. Acceleration and Deceleration in the Internationalization Process of the Firm. Manag. Int. Rev. 2016, 56, 827-847. [CrossRef]

135. Kafouros, M.I.; Buckley, P.J.; Sharp, J.A.; Wang, C. The role of internationalization in explaining innovation performance. Technovation 2008, 28, 63-74. [CrossRef]

136. Abubakar, Y.A.; Hand, C.; Smallbone, D.; Saridakis, G. What specific modes of internationalization influence SME innovation in Sub-Saharan least developed countries (LDCs)? Technovation 2019, 79, 56-70. [CrossRef]

137. Bortoluzzi, G.; Kadic-Maglajlic, S.; Arslanagic-Kalajdzic, M.; Balboni, B. Innovativeness as a driver of the international expansion of developing markets' firms: Evidence of curvilinear effects. Int. Mark. Rev. 2018, 35, 215-235. [CrossRef]

138. Cheng, L.K. Three questions on China's "Belt and Road Initiative". China Econ. Rev. 2016, 40, 309-313. [CrossRef]

139. Bascle, G. Controlling for endogeneity with instrumental variables in strategic management research. Strateg. Organ. 2008, 6, 285-327. [CrossRef]

(C) 2020 by the authors. Licensee MDPI, Basel, Switzerland. This article is an open access article distributed under the terms and conditions of the Creative Commons Attribution (CC BY) license (http://creativecommons.org/licenses/by/4.0/). 